\title{
SMALL COMPANIES AND VALUE CAPTURE FROM THEIR INTELLECTUAL PROPERTIES: A QUALITATIVE STUDY
}

\author{
by \\ Ziren Wang, B.B.A., University of Toronto: Toronto, 2014

\begin{abstract}
A thesis presented to Ryerson University
in partial fulfillment of the requirements for the degree of

Master of Science in Management

in the program of

Master of Science in Management
\end{abstract}

Toronto, Ontario, Canada, 2019

(C) Ziren Wang, 2019 


\begin{abstract}
AUTHOR'S DECLARATION
I hereby declare that I am the sole author of this thesis. This is a true copy of the thesis, including any required final revisions, as accepted by my examiners.

I authorize Ryerson University to lend this thesis to other institutions or individuals for the purpose of scholarly research.

I further authorize Ryerson University to reproduce this thesis by photocopying or by other means, in total or in print, at the request of other institutions or individuals for the purpose of scholar research.
\end{abstract}

I understand that my thesis may be made electronically available to the public. 


\begin{abstract}
Title: Small companies and value capture from their intellectual properties: a qualitative study Name: Ziren Wang

Degree: Master of Science in Management

Program: Master of Science in Management

University: Ryerson University

Year: 2019
\end{abstract}

Small companies and their intellectual properties (IPs) play an increasingly crucial role in a "well-functioning market economy". In recent empirical studies, it is recognized that small companies carried out breakthrough IPs. However, more studies are needed to investigate how small companies strategically capture value from their IPs given their resource constraints. By analyzing the empirical case findings in the light of IP management theory and resource-based view (RBV), this study attempted to answer 1) how small companies capture value from their intellectual properties and 2) in their value capture, how small companies utilize their physical, organizational, and human capital resources and overcome resource constraints, if any. Interview data with seven case companies which possess valuable and radical IPs were used to identify patterns and differences among the value capture strategies. The results were reported on a within- and cross-cases basis, which led to the discussion of three propositions. Overall, this thesis identified how small companies commercialize their IPs and the crucial roles of network and radical patents for small companies. 


\begin{abstract}
ACKNOWLEDGMENTS
Thank you, first and foremost Dr. Sui Sui and Dr. Horatio M. Morgan, my supervisors for this thesis from the Ted Rogers School of Management (TRSM). Thank you, Dr. Sui and Dr. Morgan, for your guidance, trust and support from day one when I reached out in August 2017, and for adopting me for this thesis and your crucial role in helping me navigate through everything starting from the research questions, literature review, REB application, to case selection, result analysis, and finalizing three propositions.

Thank you, Dr. Dale Carl, for chairing my Examination Committee. Thank you, Dr. Charlene Nicholls-Nixon and Dr. Dave Valliere, for serving on my Examination Committee. I wish I could have taken your courses to learn more from you. Thank you also to the other TRSM faculty members along with my 20-month-long journey, and especially to Dr. Yuanshun Li and Dr. Hong Yu for oversight of the graduate program.
\end{abstract}




\section{TABLE OF CONTENTS}

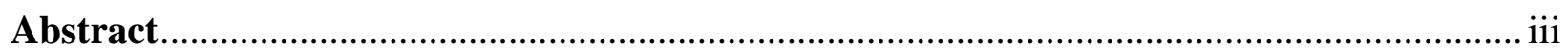

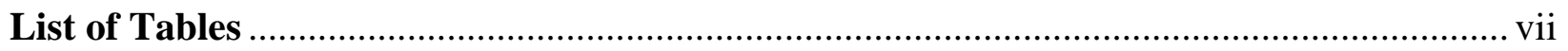

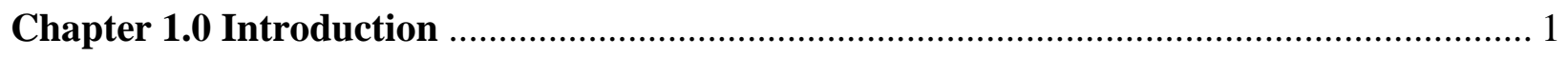

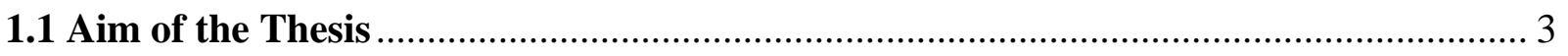

Chapter 2.0 Literature Review ............................................................................. 4

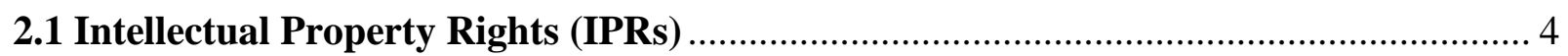

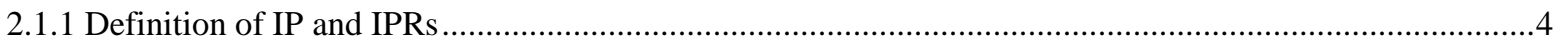

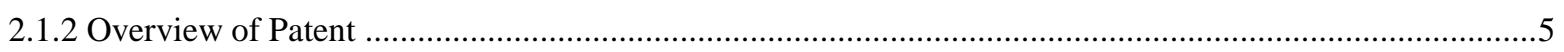

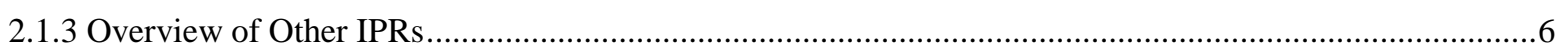

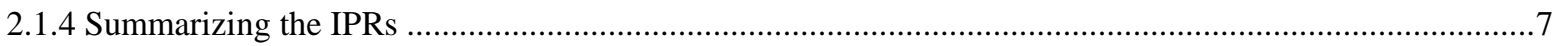

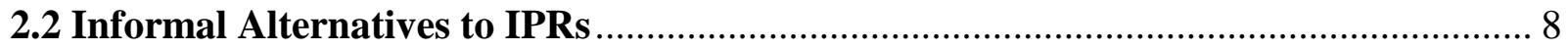

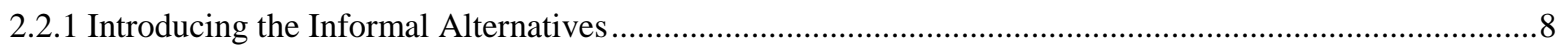

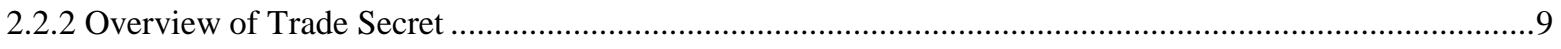

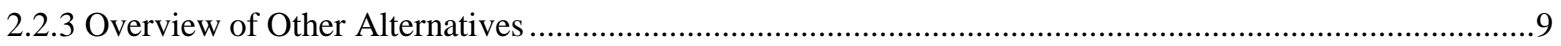

2.2.4 Joint Use of the Protection Mechanisms ......................................................................................... 10

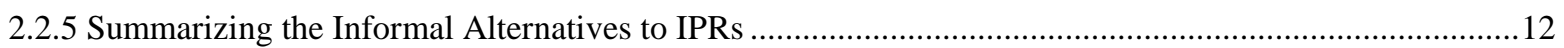

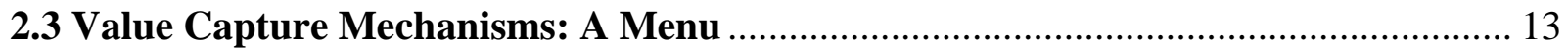

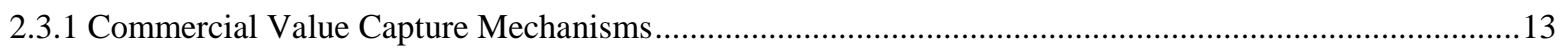

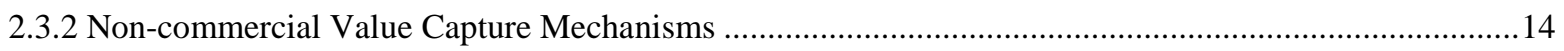

2.3.3 Summarizing the Menu of Value Capture Mechanisms ......................................................................15

2.4 Influences of Resources: Small Companies \& Value Capture ................................. 15

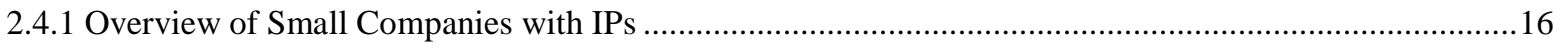

2.4.2 Resource-based View: Advantages and Challenges of Small Companies .............................................17

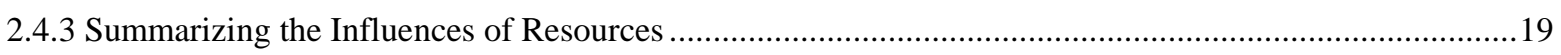

2.5 Summarizing the Literature Review ................................................................ 20

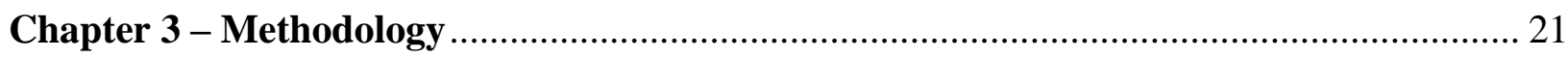

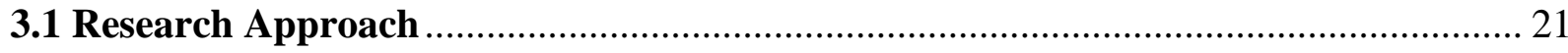

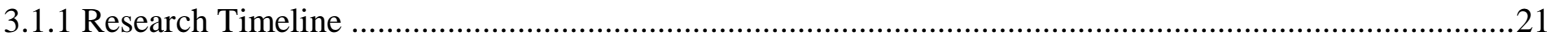

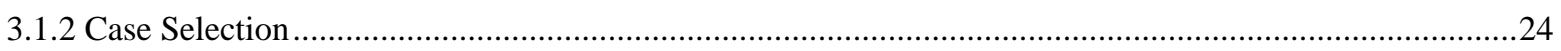

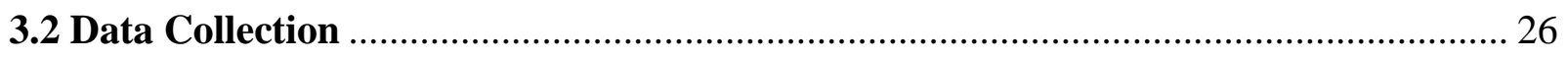

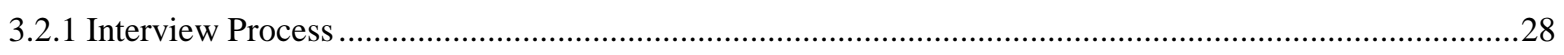

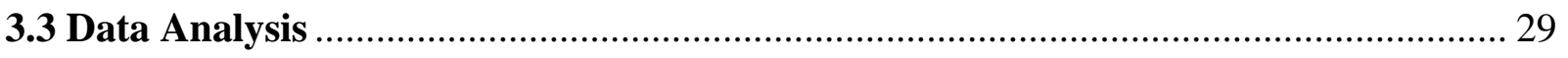

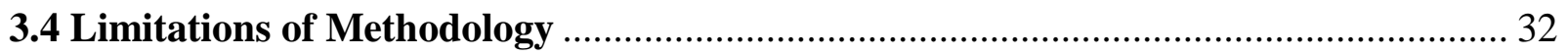




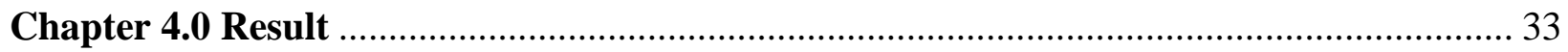

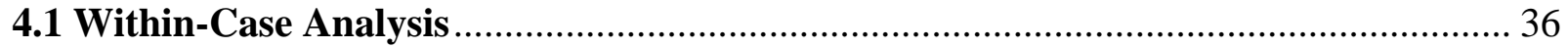

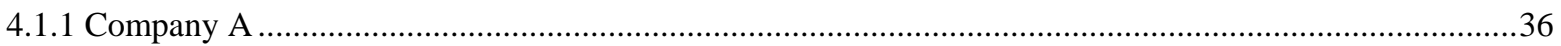

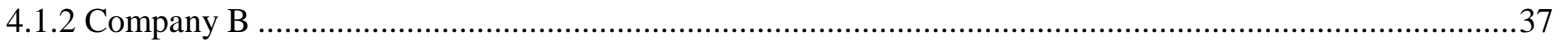

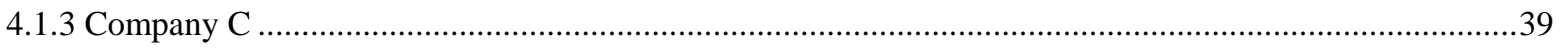

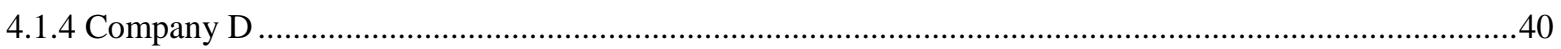

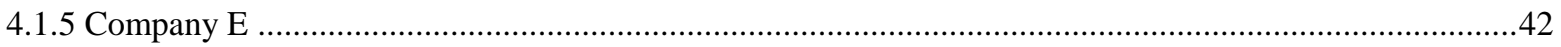

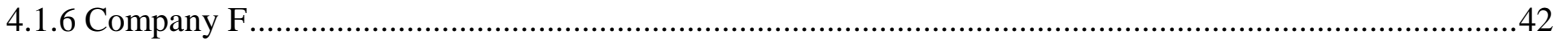

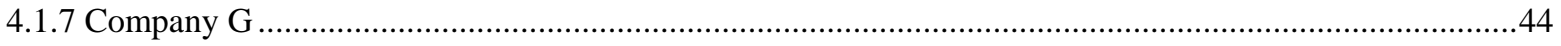

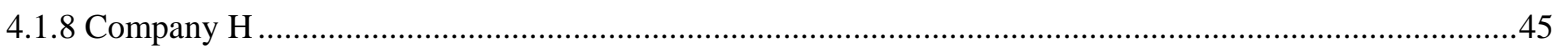

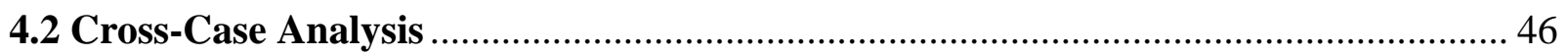

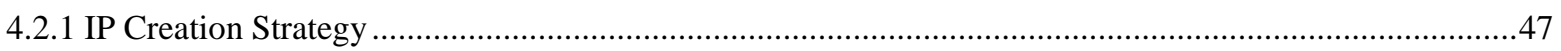

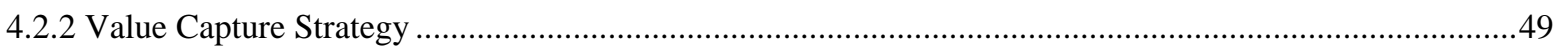

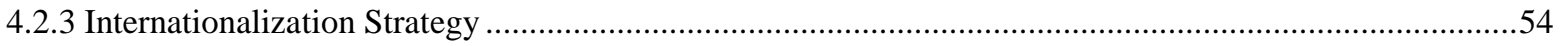

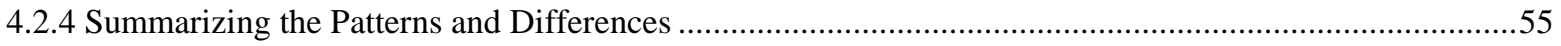

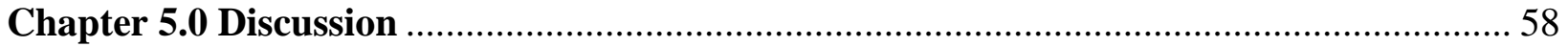

5.1 The Importance of Different Forms of Resources..................................................... 58

5.1.1 Organizational Capital Resources: Being Creative and Quick ........................................................58

5.1.2 Physical Capital Resources: Complementary Assets ...................................................................59

5.1.3 Human Capital Resources: Knowledge, Capabilities, and Network ................................................59

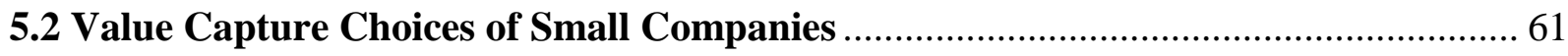

5.2.1 Commercial Value Capture: the Product Market ..............................................................................61

5.2.2 Non-commercial Value Capture: Role of Patenting......................................................................63

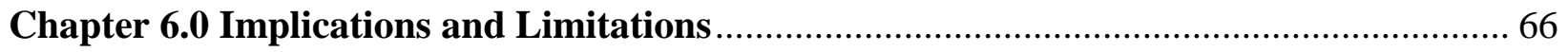

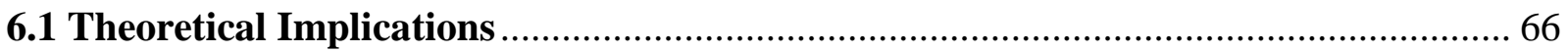

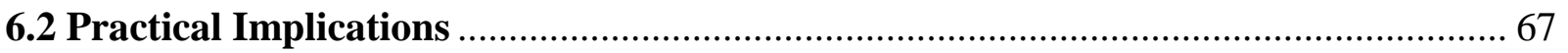

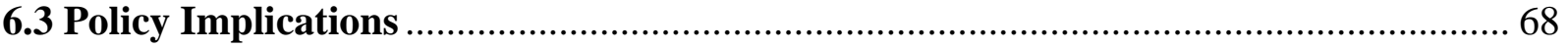

6.4 Limitations and Directions for Future Research ………………………………......... 69

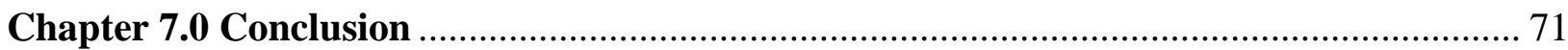

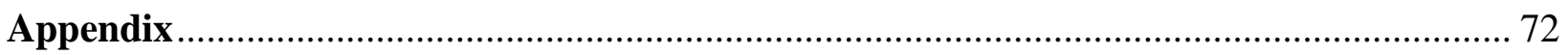

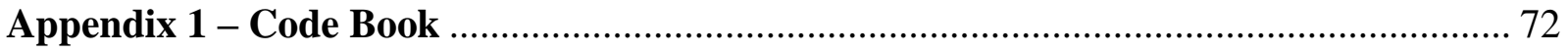

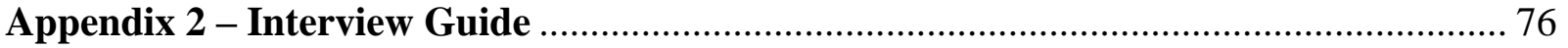

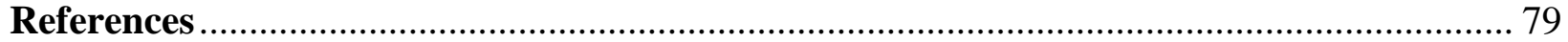




\section{LIST OF TABLES}

Table 1 - Joint Use of Protection Mechanisms for Value Capture from IPs ........................... 11

Table 2 - Example Interview Questions ............................................................................. 27

Table 3 - Overview of Data Collection ............................................................................. 29

Table 4 - Example of applying line-by-line coding to interview 6 (the Company F) data ......... 30

Table 5 - Overview of Case Companies $(\mathrm{A}$ - D) ................................................................. 34

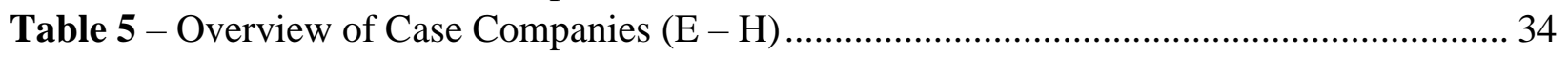

Table 6 - Patterns and Differences Among Seven Case Companies ....................................... 57 


\section{Chapter 1.0 Introduction}

Creating and capturing value from intellectual properties (IPs) have traditionally regarded as the privileges of large corporations. In reality, small companies and their IPs play an increasingly crucial role in a "well-functioning market economy" (Gans \& Persson, 2013, p. 131). It is argued that small companies in several business sectors are creating major breakthrough IPs while large companies have carried out important but only routinized ones (Baumol, 2004; Henkel, Rønde, \& Wagner, 2015). For small companies to survive and thrive in the market, the primary management goal is to capture value from their promising IPs. That is to say: small companies should translate their IPs into "a stream of economic returns for their founders, investors, and employees" (Gans \& Stern, 2003, p. 333).

In a company, IP is knowledge-based capital created by mind (WIPO, 2012), and it, which is under the category of intangible assets, includes inventions, new technologies, software, processes, and so forth; in addition, IP carries commercial value in the market (Canadian Intellectual Property Office, 2016). In order to successfully capture value from IPs, companies usually choose from various formal and informal protection mechanisms to secure their rights before value capture. Formal IP protection mechanisms, also known as intellectual property rights (IPRs) include patent, trademark, industrial design, and so forth (Gallié \& Legros, 2012; WIPO, 2012). On the other hand, companies can choose informal protection mechanisms such as trade secret, lead time, design complexity along with others (Gallié \& Legros, 2012; Thomä \& Bizer, 2013). Companies can use a single mechanism or multiple mechanisms jointly to enhance and enable the value capture from their IPs (Neuhausler, 2012). Nonetheless, previous studies 
have mainly focused on the use of a single IP protection mechanism, particularly the mutual exclusivity of patent versus trade secret (Gallié \& Legros, 2012; Thomä \& Bizer, 2013).

Value capture, also known as appropriation or commercialization in the line of literature on IP, is to secure the return on investments in developing ideas and bringing them to market (e.g., Neuhausler, 2012; Teece, 1986). As mentioned earlier, capturing value from IPs is a small company's primary goal. Small companies could capture commercial value (e.g., selling products with embedded IPs), non-commercial value (e.g., attracting investors), or both from their appropriately protected IPs (e.g., Gans \& Stern, 2003; Hsu \& Ziedonis, 2013). Prior research on small companies has emphasized small companies' choices between formal and informal protection mechanisms for value capture (Gallié \& Legros, 2012; Thomä \& Bizer, 2013). Specifically, a common view is that the small companies are likely to adopt informal protection mechanisms, which is less costly as opposed to the formal mechanisms, as they are resource-poor (Leiponen \& Byma, 2009; Rassenfosse, 2012). Early studies do not fully cover the process and capture the nuances of how small companies capture value from their intellectual properties as well as how small companies utilize their resources and overcome resource constraints (Datta, Mukherjee, \& Jessup, 2015).

To join the strand of research on small companies and their IP value capture, this study investigates this phenomenon based on the resource-based view (RBV). RBV is a frequently used overarching view in the studies of small companies (e.g., Lee, Park, Yoon, \& Park, 2010; Veugelers \& Schneider, 2018). To facilitate the discussion in this study, the company "resources can be conveniently classified into three categories: physical capital resources, human capital resources, and organizational capital resources" (Barney, 1991, p. 101). Small companies have superior organizational capital resources (e.g., flat organization structure) (Petrick, Rayna, \& 
Striukova, 2014; Revilla \& Fernández, 2012) while they lack physical capital (e.g., complementary assets) (Gans \& Stern, 2003) and human capital (e.g., competencies and network) resources (Gredel, Kramer, \& Bend, 2012) when capturing value from their IPs. To complement prior research, this study addresses the gap in RBV by depicting how small companies utilize their resources that they own as well as overcome the resource constraints, which is developed from primary interview data with seven case companies.

\subsection{Aim of the Thesis}

The knowledge about how small companies protect and capture value from their IPs is limited. Therefore, this thesis aims to increase and widen the understanding of how the process of small companies' value capture unfolds with a focus on RBV. Consequently, there are two research questions:

(1) How do small companies capture value from their intellectual properties?

(2) In their value capture, how do small companies utilize their physical, organizational, and human capital resources and overcome resource constraints, if any?

The remainder of this thesis is organized into six chapters. Chapter 2 explains common IP protection mechanisms, depicts how companies capture value from their IPs in existing studies, and describes the influences of resources. Chapter 3 discusses the methodology. Chapter 4 presents the results (i.e., within-case and cross-case analysis). Chapter 5 discusses the results, and Chapter 6 discusses implications, limitations of this study and directions for future research. Finally, Chapter 7 concludes. 


\section{Chapter 2.0 Literature Review}

Multiple strands of literature have sought to discuss and explain how companies capture value from their knowledge-based assets. These assets could enable their owner companies not only to generate revenue, but to maintain competitive edges (Gans \& Stern, 2003), such as attracting investors (Hsu \& Ziedonis, 2013; Rassenfosse, 2012), improving productivity (James, Leiblein, \& Lu, 2013), forming collaboration (Gans, Hsu, \& Stern, 2002), and so forth. In order to further contribute to the understanding of this line of research, it is important to undertake some initial conceptual ground clearing (Candelin-Palmqvist, Sandberg, \& Mylly, 2012; Kitching \& Blackburn, 2003).

\subsection{Intellectual Property Rights (IPRs)}

\subsubsection{Definition of IP and IPRs}

Intellectual property (IP) refers to the knowledge-based capital created by mind, such as inventions, artistic works, and images used for commercial reasons (WIPO, 2012). In the context of a company, IP is under the category of intangible assets which include inventions, new technologies, software, processes, and so forth, which carry commercial value in the market (Canadian Intellectual Property Office, 2016). IP can be classified into four categories: “a new or significantly improved product (good or service), or process, a new marketing method, or a new organizational method" (OECD, 2005, para. 146). A company's existing and prospective competitors are eager to take a free ride on its valuable IPs; therefore, it is of great importance for a company to protect its IP appropriately. 
Intellectual property rights (IPRs) are one of the IP protection mechanisms which companies can use to protect their IPs. Similar to other property rights, IPRs allow the owner (or creator) companies to capture value from their IP (WIPO, 2012). In addition, IPRs are considered as formal IP protection mechanisms because of their statutory nature (Gallié \& Legros, 2012). Common IPRs include patents, design registrations, trademarks, and copyrights (Gallié \& Legros, 2012; WIPO, 2012), whereas patents are the most studied theme in the theoretical and empirical literature (Gallié \& Legros, 2012). Despite IPRs being theoretically effective capturing value from IP, small companies refrain from using IPRs because of their resource constraints, which is discussed later in this Chapter (Leiponen \& Byma, 2009; Thomä \& Bizer, 2013).

\subsubsection{Overview of Patent}

Much of the research on IP has focused on companies activities regarding the patent, which arguably is the strongest IP protection mechanism (Gallié \& Legros, 2012; Leiponen \& Byma, 2009). As described by the World Intellectual Property Organization (WIPO), a patent grants the exclusive commercialization rights for an IP to the patent owner, and the rights may be given or transferred to other entities if the owner decides to license or sell the patent (WIPO, 2012). Such rights generally expire in twenty years in most jurisdictions (Gallié \& Legros, 2012; WIPO, 2012).

A patent can not only grant the exclusive rights but also bring value in other forms. For example, based on evidence from 370 venture-based start-ups, Hsu \& Ziedonis (2013) finds that patents confer dual advantages through two distinct mechanisms. Patents provide owner companies with exclusive commercial rights (i.e., the barrier to entry) and on the other hands, 
patents favor companies who are seeking venture capital financing or exiting through an initial public offering.

As important as patents seem to be, companies need to conduct a thorough benefit-cost analysis before patenting their eligible IPs. On the one hand, like all other IPRs, the direct costs associated with patenting such as filing and hiring a counsel are high while there are indirect costs such as detecting infringement, managing the patent, and enforcing the right (Hall, Helmers, Rogers, \& Sena, 2013). On the other hand, the patent owner is required to disclose the patented core technologies. The disclosure enables competitors to reverse engineer, conduct further research, and innovate around the patented technologies (Gallié \& Legros, 2012), and even outperform the patent owner if they can more easily access to critical complementary assets, such as manufacturing and distribution assets, than the patenting companies (Teece, 1986).

\subsubsection{Overview of Other IPRs}

"A trademark is a distinctive sign that identifies certain goods or services produced or provided by an individual or a company" (WIPO, 2012, p. 8). Similarly to the patents, a trademark grants the owner exclusive right for the use of "protected words, signs, or symbols" (Block, De Vries, Schumann, \& Sandner, 2014, p. 525), which gives the owner competitive advantages by letting clients distinguish the trademark owner from its competitors. Unlike patents, the trademark's protection is deemed indefinitely as long as the owner renews periodically (Gallié \& Legros, 2012; WIPO, 2012).

The strategic use of a trademark can benefit a company. Taking Coke Zero and Diet Coke as an example, they enjoy the favor as distinct products of Coca Cola by taking advantages of the established image and goodwill. Interestingly, a trademark can be used in a complementary 
fashion or as a substitute to a patent depending on the owner company's industry. Llerena \& Millot (2013) show that during the patent period, the company's trademark protects its reputation when competing with other companies (i.e., substitution); after the patent's expiration, trademark enables the company to continue benefiting from its established reputations (i.e., complementarity). Besides, the empirical results of Llerena and Millot (2013) show that trademarks and patents tend to benefit companies as complementarity in chemical and pharmaceutical sectors while they are a substitute in computer product and electrical equipment (i.e., high-tech) sectors.

Industrial design, also known as design registration, increases an IP's commercial value and marketability; thus, it assures the owner's return on investment (WIPO, 2012). This legal right protects the unique visual appearance of an IP, including the "lines, contours, colors, shape, texture, materials, and the ornamentation" (Gallié \& Legros, 2012, p. 781). Industrial design is a relatively inexpensive formal protection mechanism, and it is thus attainable to both small companies and individuals (WIPO, 2012).

In addition to the most studied formal protection mechanism discussed above, other formal intellectual property rights include but not limited to copyright, geographical indication, and so forth (Alam \& Newaz, 2016; Gallié \& Legros, 2012; WIPO, 2012).

\subsubsection{Summarizing the IPRs}

In sum, IPs are the knowledge-based intangible assets created by mind in a company. In order to capture value from IPs, companies can use appropriate IPRs as protection mechanisms to claim their exclusive commercial rights. Most studied IPRs include patent, trademark, and industrial design. Using them in a complementary or substitution manner, companies can gain 
additional competitive advantages through IPRs. Even so, there are possible downsides using IPRs; particularly, being very costly.

No single IPR or the informal alternative protection mechanism, which this study discusses later, can perfectly enable companies to capture value from their IPs; therefore, this study is focused on the joint use of different mechanisms (Gallié \& Legros, 2012). Chapter 2.2 discusses informal alternatives to IPR, which completes the discussion on how to use the protection mechanisms jointly.

\subsection{Informal Alternatives to IPRs}

2.2.1 Introducing the Informal Alternatives

As attractive as IPRs seem to be, there are certain disadvantages to protect IPs by merely using formal mechanisms (Gallié \& Legros, 2012). In addition to the high-cost nature of formal IP protection mechanisms, companies are required to disclose their core technologies for the grant of a patent, and besides, some knowledge (e.g., tacit knowledge) cannot be formally protected. Accordingly, in order to mitigate the constraints of formal IP protection mechanisms, companies might use informal alternatives to enable the value capture from their IPs.

Informal IP protection mechanisms usually takes the forms of trade secrets, lead time, and design complexity (Gallié \& Legros, 2012; Hall, Helmers, Rogers, \& Sena, 2014), and debatably it can even be as broad as defensive publishing, high-trust relationships with customers and suppliers, focusing on a niche market, and building loyalty among employees (Kotala, Päällysaho, \& Kuusisto, 2010; Neuhausler, 2012; Thomä \& Bizer, 2013). Chapter 2.2.1 and 2.2.2 discuss three primary forms of inform IP protection mechanisms. 


\subsubsection{Overview of Trade Secret}

Previous literature has emphasized on the use of patents and trade secrets as key IP protection mechanisms (Gallié \& Legros, 2012; Leiponen \& Byma, 2009). By definition, a trade secret is the information a company undertakes judicious efforts to maintain secrecy, which is generally unknown to others, especially to the competitors (Gallié \& Legros, 2012). Such information should derive actual or potential commercial value, and it can be "a formula, pattern, compilation, program device, method, technique, or process" (Castellaneta, Conti, Veloso, \& Kemeny, 2016, p. 525). Taking Coke Cola as an example again, one of the most notable trade secrets is their formula for the syrup, which has been well-protected since 1891 .

As summarized by Brant \& Lohse (2013), compared to IPRs, using trade secrets does not require formalities such as registration, so they are relatively less expensive to use. More importantly, IPs does not meet the requirements for patents, and other IPRs can be protected by a trade secret, particularly for the IPs which are process innovation or products at the product development stage. As effective as it might look, the reliance on using trade secrets to protect IPs is insufficient. Other companies can independently invent or reverse engineer the products protected by a trade secret without being regarded as infringements (Brant \& Lohse, 2013; Gallié \& Legros, 2012).

\subsubsection{Overview of Other Alternatives}

As the names suggest, lead time, speed to market, or the first mover advantage is creating or improving IPs quicker than the competitors (Kotala et al., 2010). The IPs may already have moved to the next stage or generation by the time copycats emerge. This mechanism is particularly important to companies in the software and other fast-developing sectors (Kotala et 
al., 2010). It is considered the most popular and effective mechanism of moderate to high importance in several empirical studies (Hall et al., 2014; Thomä \& Bizer, 2013; Zobel, Lokshin, \& Hagedoorn, 2017). However, the lead time might be decreasingly suited as the companies grow, as smaller firms have more capabilities to respond quickly to the market (Kotala et al., 2010).

Companies may also protect their IPs using the design complexity. Usually, a new product, process, or other forms of IPs is the integration of many components, which requires a thorough knowledge in the different components and the ability to interface between them (Brusoni, Prencipe, \& Pavitt, 2001). The more complex the IP is, the less likely it is reverse engineered. Therefore, design complexity prevents other companies from successful replication (Brant \& Lohse, 2013).

\subsubsection{Joint Use of the Protection Mechanisms}

Previous studies have focused on the single use of IP protection mechanisms for companies to capture value from their IPs, especially the mutually exclusive choice between a patent versus a trade secret; the use of other mechanisms and the joint use have not received enough attention (Gallié \& Legros, 2012; Thomä \& Bizer, 2013). In reality, different protection mechanisms are not mutually exclusive; instead, they are interrelated, and companies can use them in a joint manner.

Amara, Landry, \& Traoré (2008) adapt the conceptual framework (Table 1) of Blind et al. (2003) and test how to use protection mechanisms jointly. In their study, Amara et al. (2008) find that, for example, the patent and the lead time are used jointly and the patent and the design complexity can be used as a substitute. The study by Amara et al. (2008) is limited to 
knowledge-intensive business services; however, it carries important implications for future research. By study 8,339 French companies with IPs, Gallié \& Legros (2012) reveal that companies use protection mechanisms with the same formality jointly. That is, the joint use of IPRs and the joint use of informal protection mechanisms are revealed.

Table 1 - Joint Use of Protection Mechanisms for Value Capture from IPs ${ }^{1}$

\begin{tabular}{|c|c|c|}
\hline \multirow{2}{*}{$\begin{array}{c}\text { Knowledge } \\
\text { Type }\end{array}$} & \multicolumn{2}{|c|}{ Level of Output Tangibility } \\
\hline & Tangible & Intangible \\
\hline Codified & $\begin{array}{l}\text { Patents as primary mechanism } \\
\text { complemented with copyrights, } \\
\text { trademarks and confidentiality } \\
\text { agreements }\end{array}$ & $\begin{array}{l}\text { Copyrights as primary } \\
\text { mechanism complemented } \\
\text { with trademarks and } \\
\text { confidentiality agreements }\end{array}$ \\
\hline Tacit & $\begin{array}{l}\text { Informal protection } \\
\text { mechanisms such as trade } \\
\text { secret, the complexity of } \\
\text { design, lead-time advantage on } \\
\text { competitors complemented } \\
\text { with confidentiality agreements } \\
\text { and trademarks }\end{array}$ & $\begin{array}{l}\text { Trademarks as primary } \\
\text { mechanism complemented } \\
\text { with trade secret, lead-time } \\
\text { advantage on competitors and } \\
\text { confidentiality agreements }\end{array}$ \\
\hline
\end{tabular}

\section{(Intentionally Left Blank)}

\footnotetext{
${ }^{1}$ Conceptual Framework Adapted from Amara, Landry, \& Traoré (2008), Originally from Blind et al. (2003)
} 
Neuhausler (2012) studies the use of formal and informal protection mechanisms. In the sample of 534 German companies, $39.7 \%$ of them confirm the importance of joint use of formal and informal mechanisms. Considering the pair of a patent and a trade secret, companies can use them in a complementarity or substitution fashion according to their needs. For example, the IP can be kept secret before granting a patent (i.e., complementarity). Alternatively, specific components of the same product or process can be protected by a patent while other complementary components are kept as trade secrets (i.e., substitution).

Similarly, in the empirical study of Thomä \& Bizer (2013), they find that formal and informal protection mechanisms are not mutually exclusive because many companies use them jointly. Most often, companies combine the use of trade secrecy and lead time with formal protection mechanisms (i.e., IPRs).

\subsubsection{Summarizing the Informal Alternatives to IPRs}

In conclusion, companies can turn to the informal alternative to IPRs to enable their value capture from IPs. The informal alternatives include trade secret, lead time, design complexity, and some other arguably forms such as defensive publishing and high-trust relationships with customers and suppliers.

Many prior studies have focused on the single use of one IP protection mechanism; however, different protection mechanisms should not be mutually exclusive; instead, companies can use them in a joint manner to enhance the value capture from their IPs. Chapter 2.3 introduces the menu of choices for implementing value capture. 


\subsection{Value Capture Mechanisms: A Menu}

Chapter 2.1 and Chapter 2.2 illustrate an overview of IP protection mechanisms, which enables companies to capture value from their IPs, ranging from as simple as sales of products, services, or even patents to different forms of collaboration, and even to internationalization (Thomä \& Bizer, 2013; WIPO, 2012). Value capture, also known as appropriation or commercialization in the line of literature on IP, is to secure the return on investments in developing ideas and bringing them to market (e.g., Neuhausler, 2012; Teece, 1986). For companies, the primary goal of owning IP is to capture the commercial value; however, as discussed earlier, IPs can help companies access to non-commercial value, such as securing investment, reputations, partners, and so forth, if managed properly. In this study, capturing value is referred to as the commercial value capture as well as non-commercial value capture.

\subsubsection{Commercial Value Capture Mechanisms}

As far as the concern of capturing IP's commercial value, Gans and his colleagues (2002; 2003) suggest a model of two markets: the product market and market for "ideas" (i.e., IPs). Many companies capture the value from their IPs directly through the product market; that is, companies sell products or services with embedded IPs. Meanwhile, companies can license out their IPs to "idea buyers", provide technical assistance, and receive a lump sum payment, a stream of payments (i.e., royalty), or more complex forms of payments according to the terms of the agreement. Marx \& Hsu (2015) provide further analysis that usually companies require necessary complementary assets to capture value through the product market whereas they need

to establish reputations for attracting licensee companies or securing attractive arrangements in the market for "ideas". 
Similar to the domestic product market, IPs are also effective tools for companies to capture commercial value from international markets. In the study of Symeonidou et al. (2017), companies with IPs are more likely to sell their products internationally (i.e., export), and in addition, IPs grant companies with advantages over other companies once the companies have entered one foreign country.

\subsubsection{Non-commercial Value Capture Mechanisms}

Companies can capture value from their knowledge-based assets (i.e., IPs) through external channels (i.e., collaborate with other companies) in this era (Freel \& Robson, 2017). With IPs properly protected by either formal or informal mechanisms, companies can collaborate with other companies with lessened risk of, for instance, knowledge leakage (Brant \& Lohse, 2013). The collaboration can involve companies of any size (Borys \& Jemison, 1989), and take the forms of joint ventures (including acquisition), strategic alliances, buyer-supplier arrangements, and so forth (Brant \& Lohse, 2013; Gans \& Stern, 2003).

Companies can capture several types of value through collaboration from sharing essential knowledge, resources, capabilities and so forth. As Gans \& Stern (2003) point out in their study, collaboration enables companies to not only avoid competition and duplicated investments in complementary assets but also boost the value of their IPs by developing complementary technologies. Particularly for an IP protected by the patent, in which case patents can bridge the asymmetric information between companies and investors. Therefore, patents help companies to capture value through securing investments (Hsu \& Ziedonis, 2013; Rassenfosse, 2012). Even though collaboration overcomes the requirement of investment in complementary 
assets, it requires reputations of the companies in order to have strong bargaining power (Gans \& Stern, 2003; Marx \& Hsu, 2015).

\subsubsection{Summarizing the Menu of Value Capture Mechanisms}

After choosing appropriate IP protection mechanisms, companies have a menu of choices for implementing value capture of their IPs. In this study, capturing value is referred to as the commercial value capture as well as the non-commercial value capture. Concluding the value capture mechanisms, like a coin has two sides, companies capture value from their IPs at costs. In addition, capturing value from IPs involve a significant amount of nuanced differences influenced by internal and external factors (Gans \& Stern, 2003), which leads to the discussion of Chapter 2.4.

\subsection{Influences of Resources: Small Companies \& Value Capture}

Chapter 2.3 illustrates the value capture mechanisms for companies to benefit from their IPs. Many studies have focused on the strategies of large companies, for whom capturing value from IPs is enough with a single strategy provided their abundant resources and strong reputations (Marx \& Hsu, 2015). For scholars who study small companies on capturing value from IPs, they highlight environment factors influencing strategic choices of companies, such as competition environment, IPR regime, market size, complementary asset environment, and so forth (e.g., Gans \& Stern, 2003; Katila \& Shane, 2005; Teece, 1986). In contrast, this study focuses on small companies because of their crucial role in the IP field. In addition, they tend to be resource-poor and arguably, require a more dynamic and strategic process to protect and capture value from their IPs than the large companies (Marx \& Hsu, 2015). 


\subsubsection{Overview of Small Companies with IPs}

By definition, small companies are entities that hire 1 to 99 paid employees (Innovation, Science and Economic Development Canada, 2016). In general, small companies are essential contributors to a country's employment, job creation, and economic development (Brant \& Lohse, 2013). According to Innovation, Science and Economic Development Canada (2016), in Canada, $97.9 \%$ of businesses were small companies, which employed $70.5 \%$ of the total workforce as of 2015. In the same study, small companies were shown to contribute to approximately $30 \%$ of the gross domestic product (GDP) in 2014; furthermore, from 2005 to $2015,87.7 \%$ of new jobs created was attributed to small companies in Canada.

Remarkably, small companies accounted for $27 \%$ of total research and development expenditures to create valuable IPs (Innovation, Science and Economic Development Canada, 2016). As indicated by Statistic Canada's Survey on Financing and Growth of Small and Medium Enterprises 2014, 41.7\% of small businesses in Canada have at least one valuable IP as of 2014 (Innovation, Science and Economic Development Canada, 2015). Similarly, in the United Kingdom, approximately $33.3 \%$ of companies, most of which were small firms had valuable IP as self-reported in Community Innovation Survey (Hall et al., 2013).

Indeed, among all the businesses with valuable IPs, small companies and their IPs play an increasingly crucial role in a "well-functioning market economy" (Gans \& Persson, 2013, p. 131). As summarized by Gans \& Persson (2013), in the United States, small companies have tended to create major breakthrough IPs while large companies have carried out important but only routinized IPs, for example, incremental components to breakthrough IPs, increased reliability and user-friendliness (Baumol, 2004). Henkel, Rønde, \& Wagner (2015) provide further 
evidence by conducting a qualitative empirical study of the electronic design automation (EDA) sector, and they find that small companies carry out breakthrough IPs; besides, they argue that the finding can be generalized to other similar sectors, such as software-based sectors.

\subsubsection{Resource-based View: Advantages and Challenges of Small Companies}

Based on the resource-based view (RBV), a frequently used overarching view in several studies of this topic (e.g., Lee, Park, Yoon, \& Park, 2010; Veugelers \& Schneider, 2018), small companies are perceived resource-poor, which refrains them from creating and capturing value from IPs. The key assumptions of RBV are that resources are distributed across companies with heterogeneity and the heterogeneity is long-lasting. Wernerfelt (1984) first sheds new lights on the company's strategic choices from the resource perspective rather than looking to the productmarket side. Following this new perception, Barney (1991) suggests that companies are different combinations of resources, which is the resource heterogeneity. Companies access to their respective competitive advantage mainly stemming from their resource combinations to the extent that the resources are valuable, rare, inimitable, and with low substitutability (Barney, 1991).

To facilitate the discussion, the company "resources can be conveniently classified into three categories: physical capital resources, human capital resources, and organizational capital resources" (Barney, 1991, p. 101). Physical capital resources consist of physical technology, plant and equipment, geographic location, and so forth of a given company (Barney, 1991). Human capital resources, operationalized as years of training and work, include such as education, work experience, business start-up experience, and all types of capabilities, and the network of employees in a given company (Lundberg \& Rehnfors, 2018; Ucbasaran, Westhead, 
\& Wright, 2008). Organizational capital resources are relatively internalized by a given company, which are embedded in organizational and managerial processes and structures, such as information flow structure, planning, and controlling (Barney, 1991; Belgraver \& Verwaal, 2018). These resources can be an enabler of how to conceive and implement strategies (Barney, 1991). Specifically, for the purpose of this study, the resources are perceived influential on small companies and their value capture strategies from IPs.

Small companies have advantages to create valuable IPs from the perspective of organizational capital resources. Petrick, Rayna, \& Striukova (2014) argue that due to their flat organization structure, small companies are capable of developing IP even more quickly and effectively than the larger companies. Similarly, Revilla \& Fernández (2012) claim that small companies are relatively unbureaucratic, which results in faster information flows and more flexibility and creativity than large companies. Furthermore, small companies' geographic proximity to universities or research centers (i.e., one form of the physical capital resources) enables them to do well in creating IPs (Audretsch \& Vivarelli, 1994; Rogers, 2004). With that being said, small companies still need various other resources in order to capture value from IPs (Lawson \& Samson, 2001).

As far as the concerns of human capital resources and other critical physical capital, small companies have shown significant weaknesses in prior theoretical and empirical studies. As discussed earlier, the high-cost and high-risk nature of value capture from IPs require companies to have rich resources especially strong financial and R\&D capabilities (Alam \& Newaz, 2016). Gredel, Kramer, \& Bend (2012) summarize that financial resources, access to complementary assets, and related competencies are major obstacles for companies with regard to value capture from IPs. Similarly, Gans \& Stern (2003) claim that small companies are 
constrained by resources, such as investments in complementary assets, capabilities to manage uncertainty and establish market presence, and resources to respond to the competitive action of established companies and to capture commercial value through the product market. Furthermore, Motohashi (2008) find that small companies are more likely to license out their IPs, because they usually lack the complementary assets, such as manufacturing and distribution assets, to capture value from their IPs, so that licensing-out is imperative for them to stay afloat. Nonetheless, small companies still face another barrier stemming from resources to capture value through licensing their IPs, which is having difficulties finding proper licensees (Rassenfosse, 2012).

Last but not least, successfully capturing value from IPs requires companies to bridge multidisciplinary competencies, such as management, entrepreneurship, engineer, law, and so forth (Aarikka-Stenroos, Sandberg, \& Lehtimäki, 2014; Baldwin \& Johnson, 1996; Datta et al., 2015). However, as pointed out by Gredel et al. (2012), small companies with valuable IPs have heavily invested in their IPs at the cost of other competencies, which is particularly obvious in the context of internationalization.

\subsubsection{Summarizing the Influences of Resources}

As for the company resources, they include physical capital resources, human capital resources, and organizational capital resources. As for small companies, they and their IPs play an increasingly crucial role. Given the resources owned by small companies, they have advantages and disadvantages compared to large companies, when capturing value from IPs. Based on previous studies, small companies have a flat organization structure (i.e., organizational capital resources) to facilitate IP development and value capture positively. In some cases, they enjoy the geographic proximity to R\&D cluster. However, they are refrained 
from value capture by their limited combination of physical capital and human capital resources, such as financial resources, access to complementary assets, and required competencies.

\subsection{Summarizing the Literature Review}

Early studies of IP value capture have not only lacked in the holistic views of IP protection mechanisms to facilitate the value capture mechanisms but also lacked in capturing the subtle nuances for small companies which are usually perceived as resource-limited. In other words, it is necessary to bridge the existing IP management theories and RBV to answer the questions of how small companies capture value from their IPs provided their limited resources (Candelin-Palmqvist et al., 2012). As introduced in the existing studies, small companies face choices of formal (e.g., patent and trademark) and informal (e.g., trade secret and lead time advantages) IP protection mechanisms and they deploy the mechanisms individually; however, in reality they deploy distinct mechanisms jointly. With the appropriate protection mechanisms, small companies are enabled to capture value, which includes commercial value and noncommercial value, from their IPs. However, in order for small companies to conduct the value capture successfully, they should integrate different types of resources (i.e., physical capital, human capital, and organizational capital resources) strategically. This thesis aims to investigate the commercial and non-commercial value capture of small companies with a focus on their resource utilization and mobilization.

(Intentionally Left Blank) 


\section{Chapter 3 - Methodology}

\subsection{Research Approach}

Provided that the purpose of my study is to increase the understanding and answer questions of how small companies capture value from their IPs with their perceived limited resources, an exploratory approach was chosen. An exploratory approach is desirable since 1) the joint use of different mechanisms to capture value from IPs is fairly new (Gallié \& Legros, 2012; Thomä \& Bizer, 2013), 2) there are nuanced differences in this specific field (Datta et al., 2015; Gans \& Stern, 2003), and 3) qualitative study in this field is desirable to answer "how" and "why" questions (Candelin-Palmqvist et al., 2012). Specifically, the case study approach is appropriate (Eisenhardt \& Graebner, 2007). Furthermore, the methodology of case studies is chosen for the study taking the perspective of RBV because participants are likely to give sensitive, confidential, or consequential data (Rouse \& Daellenbach, 1999). Last but not least, case studies could offer a more nuanced picture of the process of how small companies capture value from their IPs (Datta et al., 2015).

\subsubsection{Research Timeline}

Figure 1 summarizes the timeline of this study's data collection and analysis. Starting in June 2018, I conducted preliminary interviews with business practitioners in order to design the interview guide. In early July 2018, I submitted my Research Ethics Board (REB) protocol application at Ryerson University; meanwhile, I was still conducting preliminary interviews. At the end of August 2018, my REB protocol application was approved, and then I sent out formal 
invitations for interviews to business practitioners. Due to the busy schedules of business practitioners, the interview process was prolonged than I initially expected. I managed to conduct the first interview in October 2018 and the last interview at the end of November 2018. In between the interviews, I transcribed the recording of interview data.

Finally, I finished the data collection and transcription in mid-December 2018 and thereafter, I started to analyze the interview data. During my analysis, I sent out emails for follow-up clarifications and additional information in order to fully comprehend the case companies. The whole process ended in February 2019.

(Intentionally Left Blank) 
Figure 1 - Timeline of Data Collection and Data Analysis

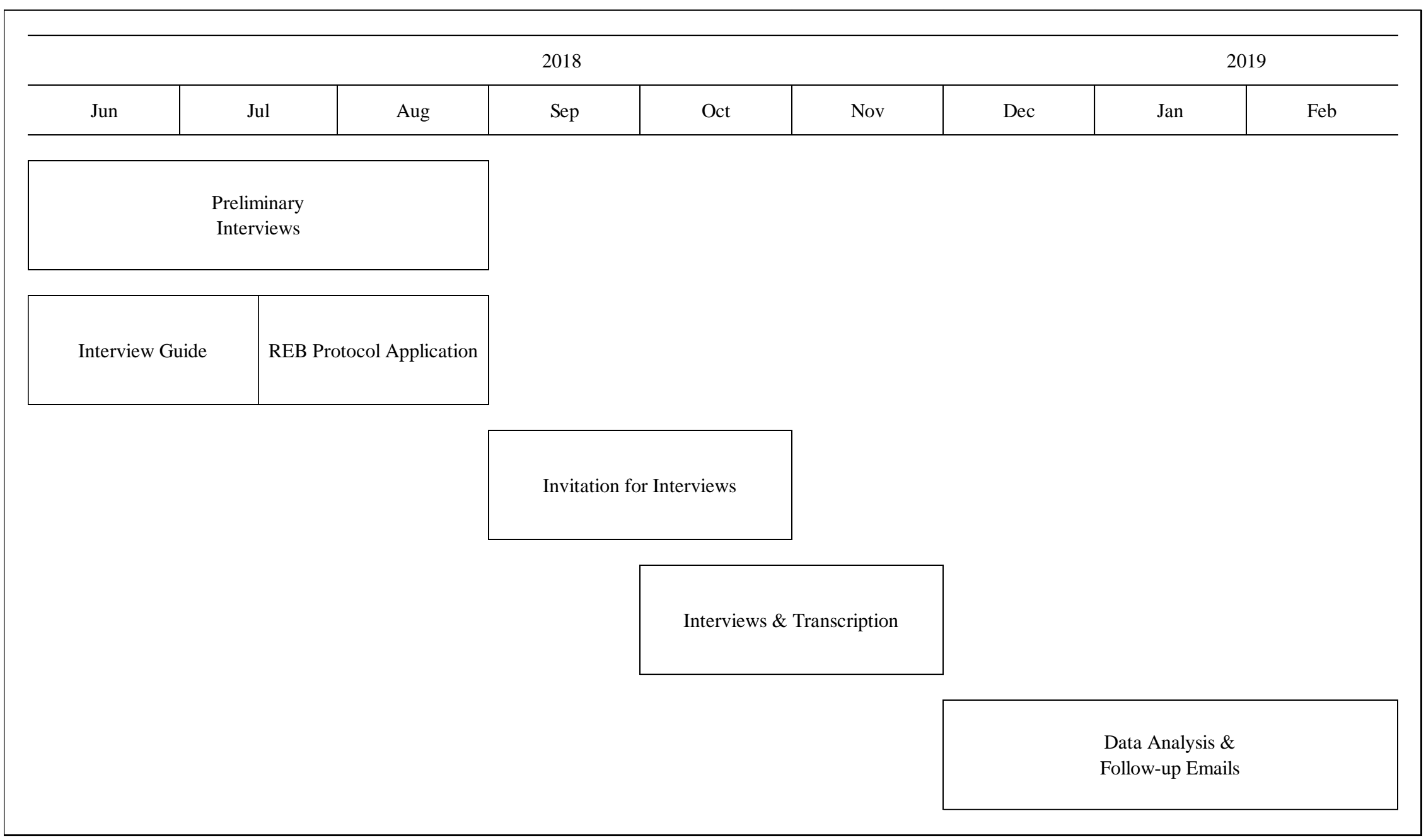




\subsubsection{Case Selection}

As suggested by Eisenhardt (1989), the sample selection should be for theoretical purposes, so the sample was not intended to be either random or representative. Furthermore, I enhanced the robustness and increased the accuracy of the analysis by choosing case companies fitting in the same criteria. Accordingly, I collected the sample by means of a "purposeful strategy" to investigate small companies which possess the following features (Locke, 2003):

(1) Small companies, as defined by Innovation, Science and Economic Development Canada (2016), as companies that have $1-99$ paid employees.

(2) Be a Canadian company as well as originally founded in Canada.

(3) Have valuable IPs, for example, inventions, new technologies, software, and processes, which carry value in the market (Canadian Intellectual Property Office, 2016).

The first two criteria were chosen because the Government of Canada is heavily investing in IP development and value capture with a focus on small companies (Innovation, Science and Economic Development Canada, 2018). The last criterion was chosen since if the company did not have valuable IP yet, the data collected from the interviews would have a risk of being unreliable due to non-execution of the strategies. Finally, Canadian small companies were also chosen as a criterion as it granted me not only the easier access to the companies but also the enhanced practicality of my study in the context of Canada.

Sharing the common characteristics as described above, the case companies had different target customers with diverse products and/or services. The interview participants were Owners, Founders, or Senior Managers responsible for their companies, especially in charge of the value capture from IPs. Their companies could be either nation-wide or province-wide. 
Compiling the sample was challenging. Prospective participants fear to lose their privacy, confidentiality and competitive edges of their respective companies, so their IPs and related strategies are not identifiable from the public sources (e.g., Internet). Therefore, I could not hinge on public information to select my sample. Since the Owners, Founders, or Senior Managers of small companies were actively gaining exposure to the business community, such as incubators and business contests, they were likely to disclose their IPs and related value capture strategies in these contexts. From there, I built rapport with business practitioners and invited them to participate in my interview. I adopted a snowballing approach where some participants introduced other qualified prospective participants from their business connections to me. This allowed me to effectively identify qualified small companies. These participants were the ideal source of information about the value capture from IPs, which is central to my research questions.

I interviewed eight case companies and I assigned letters from A through $\mathrm{H}$ as their code names (i.e., Company A through Company H). However, I conducted my analysis (Chapter 4) and developed the discussion (Chapter 5) primarily from seven interviews. I excluded Company E because this company was under restructuring phase. Company E's history before restructuring resembled Company A while its outlook was not valid for my study. Accordingly, I intentionally excluded Company E. The remaining companies (except for Company G, which was founded in 2007) were all founded in Canada during the last one decade; they have valuable IPs and have different size and revenue. Company A and B were young, and they were featured by their student-created IPs with proven value through business contests. Company $\mathrm{C}$ and $\mathrm{F}$ were relatively mature companies which started their value capture endeavors. However, Company C was service-based whereas Company F was product-based. Company D and Company G were well-funded medical device companies. Nonetheless, their value capture trajectories are 
moderately distinct. Company $\mathrm{H}$ was identified as this company captured value from IPs through two mechanisms.

Accordingly, I selected the case with an attempt to identify case companies that would provide data, with which I could use to see patterns or differences if any. The homogeneity (i.e., three criteria) and heterogeneity, such as distinct revenue, number of employees, products and services, types of IPs, of case companies ensure the high-level validity in my study (Saunders, Lewis, \& Thornhill, 2009).

\subsection{Data Collection}

Data collection involved inductive interviews using the procedures outlined by Eisenhardt (1989). I conducted in-depth, semi-structured interviews with open-ended questions in order to have a thorough comprehension of small companies and their IP value capture strategies from those having practiced or practicing it. As mentioned earlier, Owners, Founders, or Senior Managers of small companies were major participants because of their direct and practical experience with the company's IPs and related strategic decision-making processes. In Company D and G, the participants were the executors of IP-related strategies; however, both of them were knowledgeable with the decision-making processes and rationales.

I built up the topics used in the interview guide progressively, based on theoretical work on value capture from IP as well as my own preliminary interviews. Accordingly, the initial interview guide was structured around five foundations: the general business information, including size, age, and sector of companies in question; the general information of Owners, Founders, Senior Managers, including their age, education, past experience (e.g., start-up, 
industry, IP, and international business) and their respective roles and responsibilities in their particular case companies; business operation information such as resources owned, markets served, international orientation, and so forth; IP strategies including the chosen IP protection and value capture mechanisms; and the operational and financial performances, if any. The language of "what, who, where, why, when, and how" was used to guide each interview (Pettigrew, Woodman, \& Cameron, 2001, p. 700). For each interview, I started with a set of general questions on their business and core team members so that the participants would naturally bring up the matters regarding strategic uses of IPs, in their own words, without me imposing pre-structured topics. In this manner, the participants were likely to provide sensitive, confidential, and consequential data (Rouse \& Daellenbach, 1999). As shown in Table 2, it illustrates some example questions which I asked in the interviews.

Table 2 - Example Interview Questions

1. How old is your company?

2. What is the size (measured by the number of employees) of your company?

3. Who are the key individuals in your company, such as Owner, Founder, and Senior Manager?

4. What is the education background of key individuals?

5. What is their prior work (start-up, industry, IP, and international business) experience of key individuals?

6. What does your business precisely offer (new or improved products/services/production processes/organizational method/selling method)?

7. What are your IP strategies?

8. Has your company used any less formal (informal) methods to protects your IP?

9. Did internationalization play any part in your decisions regarding IP? 
With the increase in data collected, I refined the topics based on the interview data, such as how their network might provide supports. Like all other studies of this type, I further developed the interview guide as the research moved forward (Eisenhardt, 1989). In addition, I was attentive to avoiding "leading-the-witness questions" throughout my data collection (Gioia, Corley, \& Hamilton, 2013, p. 19). All the interviews lasted 30 to 60 minutes, which were recorded and transcribed verbatim. In order to fully comprehend the case companies, I collected data about the case companies from their websites; also, I sent out emails for follow-up clarifications and additional information afterward.

\subsubsection{Interview Process}

Within one week before each interview, I sent the consent form and interview guide to participants for them to understand my research topic and themes covered. Therefore, I collected data which was well researched and compiled by each participant. Before each interview, I requested their consents to record the interview for later transcribing. Afterward, I allowed participants to read the transcribed interview and correct any misconceptions to ensure the reliability of the data. Table 3 summarizes the interview and data collection.

(Intentionally Left Blank) 
Table 3 - Overview of Data Collection

\begin{tabular}{|c|c|c|c|}
\hline Company & Type & Length & Participant \\
\hline $\mathbf{A}$ & $\begin{array}{l}\text { Preliminary and in-person } \\
\text { Interview \& Phone Follow-up }\end{array}$ & $\begin{array}{c}60 \\
\text { Minutes }\end{array}$ & Co-Founder \\
\hline B & $\begin{array}{l}\text { In-person Interview \& } \\
\text { Email Follow-up }\end{array}$ & $\begin{array}{l}30-60 \\
\text { Minutes }\end{array}$ & Co-Founder \\
\hline $\mathbf{C}$ & $\begin{array}{l}\text { Preliminary \& In-person } \\
\text { Interviews }\end{array}$ & $\begin{array}{l}30-60 \\
\text { Minutes }\end{array}$ & Founder \& CEO \\
\hline $\mathbf{D}$ & Phone \& Email Follow-up & $\begin{array}{l}30-60 \\
\text { Minutes }\end{array}$ & $\begin{array}{l}\text { Commercialization } \\
\text { Manager }\end{array}$ \\
\hline $\mathbf{E}$ & Phone Interview & $\begin{array}{c}60 \\
\text { Minutes }\end{array}$ & Founder \\
\hline $\mathbf{F}$ & In-person Interview & $\begin{array}{l}30-60 \\
\text { Minutes }\end{array}$ & Co-Founder \\
\hline $\mathbf{G}$ & $\begin{array}{l}\text { Preliminary \& In-person } \\
\text { Interviews }\end{array}$ & $\begin{array}{c}60 \\
\text { Minutes }\end{array}$ & $\begin{array}{l}\text { Commercialization } \\
\text { Manager }\end{array}$ \\
\hline $\mathbf{H}$ & Preliminary \& Phone Interviews & $\begin{array}{c}30 \\
\text { Minutes }\end{array}$ & Founder \& CEO \\
\hline
\end{tabular}

\subsection{Data Analysis}

Due to the nature of data type (i.e., multiple but comparable case companies), I adopted the open coding methodological tool, specifically, line-by-line coding (Price, 2010). In addition, open coding is the initial step to systematically analyze and categorize raw data, which limit my subjectivity (Price, 2010). Furthermore, line-by-line coding minimizes the occurrence of missing an important category and so forth (Holton, 2007). For example, in Extract 1, I would have coded the sample text as "importance of patenting" if I had not coded line by line. As illustrated in Table 4, there should be five different codes explaining different aspects of patents. I applied open coding to three of the eight interview transcriptions. After the open coding, I had one hundred and twenty three (123) raw codes. 
Extract 1 - Interview 6 (the Company F)

Question: Why did you make the decision to apply for patents?

Answer: It [applying for patents] is expensive; however, there are three (types of) value [patents] bring to the table. One is the deterrence of potential competitors... The second one is to enforce and protect our interests, [allowing us] to use the patent in a financially viable way... The third one is the value that it carries for potential investors or potential exits down the road....

Table 4 - Example of applying line-by-line coding to interview 6 (the Company F) data

\begin{tabular}{|l|l|}
\hline \multicolumn{1}{|c|}{ Sample Text } & \multicolumn{1}{c|}{ Coding } \\
\hline $\begin{array}{l}\text { It [applying for patents] is expensive; } \\
\text { however, there are three (types of) } \\
\text { value [patents] bring to the table. One } \\
\text { is the deterrence of potential } \\
\text { competitors... The second one is to } \\
\text { enforce and protect our interests, } \\
\text { [allowing us] to use the patent in a } \\
\text { financially viable way... The third one } \\
\begin{array}{l}\text { is the value that it carries for potential } \\
\text { investors or potential exits down the } \\
\text { road.... }\end{array}\end{array}$ & $\begin{array}{l}\text { Role of patents to attract potential } \\
\text { investors }\end{array}$ \\
\hline
\end{tabular}

(Intentionally Left Blank) 
As a result of line-by-line coding, some of the codes are similar or even duplicated so I can merge them into one code. For example, "role of a patent in business development" and "role of a patent in commercialization" are similar codes. In other cases, a series of codes can be further classified in one category (i.e., the parent code). For example, I can name a code "competition" as the parent code of "advantages of competitors", "barriers to competitors", "competitors", and so forth, if needed.

In other cases, I re-coded or even deleted codes that are not useful in my analysis. For instance, when line-by-line coding, I coded the products and core technologies of case companies in a meticulous manner in order to capture the nuances that might influence their later value capture choices. However, it is likely that there is no pattern as expected. In the refining of coding and developing the code book thereafter, I coded the products and core technologies of case companies simply to capture the overview, which is adequate for the analysis. Similarly, I removed codes that were used in line-by-line coding to capture nuances but was less needed in later data analysis, such as when the participants joined or left the case companies and so forth.

As illustrated in Appendix 1, the final code book is attached. There are 63 codes in total. $60(95 \%)$ of the codes emerged after the first four interviews. In other words, after analyzing four cases, new codes emerged infrequently and progressively as the analysis moved forward. Therefore, this study reached theoretical saturation after four case interviews, which is consistent with most case study theories and research (Guest, Bunce, \& Johnson, 2006; Romney, Weller, \& Batchelder, 1986).

In sum, I continuously and iteratively analyzed the data when processing and viewing different theoretical frameworks, which ensures a reliable analysis (Eisenhardt, 1989). As 
mentioned earlier, the primary, if not all, type of analysis was text-based. I transcribed the interviews and then analyzed with QSR NVivo package, computer software designed for qualitative studies, which helped me store, organize, categorize, and analyze data, and visualize and discover insights in data. With the help of QSR NVivo package, I was not only able to conduct within-case analysis, but also could I conduct cross-case analysis such as detecting patterns, differences, and similarities among the case companies (Eisenhardt, 1989). I sent the analysis results to the participants to validate the reliability of my analysis. By within- and crosscase analysis and relating analysis to literature, I was able to validate the results against existing theoretical frameworks. Furthermore, the findings and analysis led to three propositions.

\subsection{Limitations of Methodology}

Being a qualitative case-study thesis, my results and analysis cannot be statistically tested, for example, by F statistics and the process is highly judgemental (Eisenhardt, 1989). I have applied tactics such as avoiding "leading-the-witness questions" in the interview process, constantly following up in the data analysis, open coding, sending analysis results to respective participants for verifications, and so forth. Even so, this study was limited by its scope, timeframe, and having single investigator, so other techniques such as data triangulation and intercoder reliability test. Future studies could address this issue to further enhance the rigor of this study. Other limitations are discussed in Chapter 6.4.

\section{(Intentionally Left Blank)}




\section{Chapter 4.0 Result}

As suggested by Eisenhardt (1989), I coupled the method of within- and cross-case analysis to analyze the data. The within-case analysis enabled me to gain familiarity with data, particularly each case company as a separate entity, and accelerate the later cross-case comparison. In the cross-case analysis, I analyzed the case companies based on two dimensions which are 1) distinct strategies and 2) different resources required to mitigate informationprocessing biases and enhanced the probability to capture novel findings.

I presented the data by utilizing the summary tables for both the theoretical and empirical richness (Eisenhardt \& Graebner, 2007). Table 5 is the summary table for each case company followed by the description of each case company on a within-case basis in Chapter 4.1. Similarly, in Chapter 4.2, Table 6 concludes the cross-case patterns and differences, which conveniently lead to the discussions of findings.

(Intentionally Left Blank) 
Table 5 - Overview of Case Companies $(A-D)$

\begin{tabular}{|c|c|c|c|c|}
\hline & $\mathbf{A}$ & B & $\mathbf{C}$ & D \\
\hline $\begin{array}{l}\text { Business } \\
\text { Description }\end{array}$ & $\begin{array}{l}\text { A medical } \\
\text { device that } \\
\text { simplifies a } \\
\text { complex } \\
\text { prescription } \\
\text { process at low } \\
\text { costs. }\end{array}$ & $\begin{array}{l}\text { An } \\
\text { economically } \\
\text { and } \\
\text { environmentally } \\
\text { viable } \\
\text { alternative that } \\
\text { contribute to } \\
\text { infrastructure } \\
\text { longevity. }\end{array}$ & $\begin{array}{l}\text { A platform that } \\
\text { prognoses issues } \\
\text { and provides } \\
\text { actionable } \\
\text { insights through } \\
\text { algorithms. }\end{array}$ & $\begin{array}{l}\text { A medical } \\
\text { device that } \\
\text { offers a simpler } \\
\text { method to } \\
\text { diagnose a } \\
\text { chronic disease } \\
\text { with accuracy. }\end{array}$ \\
\hline Employees & 6 & 4 & 10 & $15-20$ \\
\hline Funding & Contest prizes & Contest prizes & $\begin{array}{l}\text { Venture } \\
\text { capitalist }\end{array}$ & $\begin{array}{l}\text { The parent } \\
\text { company, } \\
\text { angel investors, } \\
\text { founders, \& } \\
\text { venture } \\
\text { capitalists }\end{array}$ \\
\hline $\begin{array}{l}\text { Revenue } \\
\text { (CAD\$) }\end{array}$ & 0 & 0 & Half million & 0 \\
\hline Founded & 2013 & January, 2018 & 2015 & 2012 \\
\hline Patent & In progress & In progress & 2 & $\begin{array}{l}\text { Patent portfolio } \\
\text { (International) }\end{array}$ \\
\hline $\begin{array}{l}\text { Informal } \\
\text { IP } \\
\text { Protection }\end{array}$ & $\begin{array}{l}\text { Trade secrets, } \\
\text { separation of } \\
\text { duties, and lead } \\
\text { time advantages }\end{array}$ & $\begin{array}{l}\text { Contracts } \\
\text { (NDA), } \\
\text { trade secrets }\end{array}$ & $\begin{array}{l}\text { Trade secrets, } \\
\text { lead time } \\
\text { advantages, } \\
\text { trusted } \\
\text { relationship }\end{array}$ & Trade secrets \\
\hline
\end{tabular}

(Intentionally Left Blank) 
Table 5 - Overview of Case Companies $(E-H)$

\begin{tabular}{|c|c|c|c|c|}
\hline & $\mathbf{E}^{2}$ & $\mathbf{F}$ & $\mathbf{G}$ & $\mathbf{H}$ \\
\hline $\begin{array}{l}\text { Business } \\
\text { Description }\end{array}$ & $\begin{array}{l}\text { A machine } \\
\text { learning and } \\
\text { project-by- } \\
\text { project model. }\end{array}$ & $\begin{array}{l}\text { An IoT } \\
\text { company } \\
\text { providing fast } \\
\text { and easy } \\
\text { security } \\
\text { solutions. }\end{array}$ & $\begin{array}{l}\text { A medical } \\
\text { device company } \\
\text { that owns } \\
\text { cutting-edge } \\
\text { technology in its } \\
\text { niche field. }\end{array}$ & $\begin{array}{l}\text { An online } \\
\text { marketplace for } \\
\text { the provision of } \\
\text { private lessons. }\end{array}$ \\
\hline Employees & 1 & Almost 20 & 90 & $6-10$ \\
\hline Funding & N/A & $\begin{array}{l}\text { Crowdfunding } \\
\& \\
\text { angel investors }\end{array}$ & $\begin{array}{l}\text { Angel investors, } \\
\text { employees, } \\
\text { venture } \\
\text { capitalists, } \\
\text { government } \\
\text { grants }\end{array}$ & $\begin{array}{l}\text { Bootstrap \& } \\
\text { government } \\
\text { grants }\end{array}$ \\
\hline $\begin{array}{l}\text { Revenue } \\
\text { (CAD\$) }\end{array}$ & 0 & $\begin{array}{l}\text { Between } \\
1-10 \\
\text { million }\end{array}$ & Below 1 million & $\begin{array}{l}\text { Low seven- } \\
\text { figure }\end{array}$ \\
\hline Founded & March 2014 & January 2016 & 2007 & 2011 \\
\hline Patent & N/A & 2 (1 in progress) & $\begin{array}{l}\text { Patent portfolio } \\
\text { (International) }\end{array}$ & In progress \\
\hline $\begin{array}{l}\text { Informal } \\
\text { IP } \\
\text { Protection }\end{array}$ & Trade secrets & $\begin{array}{l}\text { Trade secrets } \\
\text { and separation } \\
\text { of duties }\end{array}$ & Trade secrets & $\begin{array}{l}\text { Trade secrets, } \\
\text { contracts } \\
\text { (NDA), and } \\
\text { separation of } \\
\text { duties }\end{array}$ \\
\hline
\end{tabular}

(Intentionally Left Blank)

${ }^{2}$ Company E was not included either in the within- or cross-case analysis, or discussion as explained in Chapter 3. 


\subsection{Within-Case Analysis}

\subsubsection{Company A}

The interview was conducted in October 2018 after Company A paused its operation in the Summer of 2017. Thus, the following description was entirely based on Company A's then current situation as of the final date of Company A's operation.

Company A is a commercial venture based on a university design project because the concept has proved its commercial value. After the Co-Founders graduated from university with their System Design Engineers degree, they carried on the project and founded the case company. The IP of Company A is radical to the market.

The case company is in the healthcare sector, and the product is hardware along with software to generate accurate prescriptions on diseases of one particular organ. As mentioned earlier, the Co-Founders are System Design Engineers, so they collaborated with another healthcare school to fill the knowledge gap. Along with collaboration, the healthcare school provided Company A with not only knowledge supports, but also opportunities to leverage monetary supports. In addition, Company A has been funded through a variety of business contests and grants. Still, Company A has not sufficiently funded to sustain its operation.

In terms of the IP value capture, Company A is not able to commercialize it or patent on it at all due to financial constraints. However, the case company has deployed several informal protection mechanisms, such as trade secrets, separation of duties, and lead time advantages with an attempt to enable the value capture through the product market. Besides, the company in 
question has recognized the importance of patents, so Company A has put substantial efforts into properly patenting on their IPs.

Being too limited by funding to capture value from IP was not the only reason that Company A paused its operation. Besides, Company A was suffering from the loss of human capital at the end of its operation. Consequently, Company A required additional human capital to sustain its business, particularly, the value capture from IP.

In sum, even though Company A has not successfully sustained its business operation, Company A did carry valuable IP. The company in question has attempted to formalize the value capture by patenting when it has been protecting its IP through various informal mechanisms.

\subsubsection{Company B}

Company B is a radical technology start-up that tackles infrastructure space. The ideation was in September 2017, and then the foundation of Company B was in January 2018. The company's technology emerged as a school project to partially complete the master's degrees of four Co-Founders. With the development of this idea, the project was winning several business contests, so the technology has been proven its value. Therefore, the Co-Founders sensed the value and had the seed money (prizes from the contests) to found Company B and continued the project as a business venture.

The four Co-Founders were trained engineers in different steams; in addition, they were trained to start up a company, which was a significant curriculum in their master's studies. Furthermore, the program was so supportive that they could access to multidisciplinary experts 
as their mentors from school faculties and the industries to develop, protect, and capture value from their IP.

As of the interview, Company B was funded through contests as mentioned earlier. In order to secure extra funding, Company B needed a prototype so that it was able to apply for grants of a more substantial amount of money. The prototype was also crucial for Company B to demonstrate its technology to potential clients.

Currently, informal protection mechanisms (i.e., non-disclosure agreements and trade secrets) are sufficient for Company B. When it finishes designing the prototype, Company B will require a patent to further protect its technology. Then, Company B will still use trade secrets to complement the patent; the patent will mainly protect the IP-embedded product whereas trade secrets will mainly protect the know-how (i.e., tacit knowledge). Besides, the patent will also enable collaboration opportunities (e.g., licensing-out) for Company B. Notably, the IP Lawyer in the mentor network has been a great help with Company B's preliminary patenting process on a pro bono basis.

In essence, Company B is a young and promising company which has a valuable IP. Due to its financial and human capital constraints, Company B has to strategically leverage the company's network to push forward the company's IP development and value capture. Today Company B requires a patent to further proceed with the IP value capture. 


\subsubsection{Company C}

Company $\mathrm{C}$ is a platform that enabled enterprises in a particular business ecosystem to prognose issues and provides actionable insights. The core IPs of this case company are datadriven technology and radical to the market.

Founded in 2015, Company C started to capture the commercial value since 2016. Today this case company has grown to the combined size of ten employees in both Canada and the United States. Besides, Company $\mathrm{C}$ is serving multiple international markets. Company $\mathrm{C}$ is well-funded and generating revenue out of its IP-embedded products and services. Now it is securing another round of financing as well as closing out major sale contracts.

Most of the employees are on the technical side to support the developing and refining of its algorithms. As for the executives, one of the two partners owns technical skills while another one has extensive work experience in business to support the value capture from IPs.

As mentioned earlier, Company C's core IP is data-driven. As such, the underlying processes and algorithms are more valuable as opposed to the product of Company $\mathrm{C}$. The case company first collected data from its ecosystem and then focuses on one niche. After that, Company $\mathrm{C}$ develops and refines algorithms to perform tasks to meet the needs of the niche. The case company keeps iterating the algorithms to improve efficiency and accuracy. Above all, it is an overview of Company C's IPs.

As far as the concern of value capture from IPs, Company $\mathrm{C}$ has been granted two patents on one of its outputs. Other concepts (i.e., processes and algorithms) are still under the protection 
of trade secrets. Plus, as mentioned early, lead time is one of Company C's protection mechanism because it iterates faster than the peer companies.

In conclusion, the nature of Company C's core IP is data-driven technology. Therefore, the case company uses patents to protect its end output (i.e., IP-embedded products and services). However, the processes and algorithms, which carries more value than the output, are protected informally for protection purposes. In other words, the output captures value whereas the processes and algorithms to attain the output are valuable.

\subsubsection{Company D}

Company D is a spin-off of a large hospital. The company offers a medical device with substantial innovation. A group of highly educated scientists and doctors identified a problem, took on the project, and found the solution (i.e., the IP in question), which happened to carry commercial value. Therefore, the parent company applied for the patents before they spun off Company D.

The interview was conducted in November 2018, after the participant left Company D in April 2016. Thus, the following description was based on Company D's then current situation before the participant left.

As of April 2016, company D was well-funded by the parent company, parent company's partners, private investors, and the Founders. Besides, the company was raising funds from venture capitals, specifically in the Series A round.

The size of Company D was fifteen to twenty full-time employees, and due to the nature of its business, more than half of them were working on R\&D aspects of the company. The 
leadership team of Company D was composed of highly educated scientists in the related STEM (i.e., science, technology, engineering, and mathematics) field.

In terms of the rivalry, there was merely indirect competition, and two major types of conventional products had been already in the market. The first product was accurate with clinical evidence; however, it was not portable and affordable. As opposed to the first one, the second conventional product was portable and affordable but not clinically proven. Company D provided the combined benefits of both products, and its primary target market was institution users.

When it comes to the IP aspect, as described in the previous paragraph, Company D did not have direct competitors because its patent portfolio established a barrier to entry. The patent portfolio was also a signal for legitimized product and company in North America and other international markets. Besides, the patent portfolio helped Company D to secure investments in these markets. Interestingly, the patent portfolio gave the employees and investors of Company D peace of mind that the core technology would be protected from imitation.

As crucial as the patent portfolio seems to be, Company D protected the complementary programming codes as trade secrets which was not released in the patent disclosure.

In summary, Company D deployed patenting as the primary mechanism to capture value from its IPs. Furthermore, the patent portfolio has captured significant non-commercial value for the case company. Last but not least, trade secrets complementing with patent improved the value capture mechanism through enhanced protection. 


\subsubsection{Company E}

As discussed earlier, Company E was excluded from the analysis and discussion of this thesis.

\subsubsection{Company F}

Company F was founded in January 2016, and it officially started selling its first products in June 2017. The company is tackling an existing market, whereas it offers significantly improved products. In contrast to conventional products, F's products provide clients with enhanced efficiency, security, and accuracy. The clients include both individuals and enterprises. From 2016 to present, the company has grown up to a company with almost twenty full-time employees and revenue in between one to ten million.

Even though being young and a start-up, this company demonstrates its international scope and has three offices worldwide. One office is located in Canada, and there are eight employees including Co-Founders who are responsible for R\&D and business operation. The other two offices are in China, where there are nine employees responsible for R\&D only. In addition, Company F sells its products globally, partners with international distributors, and files patent applications across multiple countries.

Company $\mathrm{F}$ started out by a crowdfunding campaign, and to date, the company is wellfunded by Angel Investors. As of the interview date, the company was seeking venture capitalists to raise capital. Two young partners started out this business, and both have work experience in large corporations and successfully have started up business for one time. They have a combined 
knowledge and skill set of business, engineering, and programming to support Company F. In addition, the company has a strong and multidisciplinary middle management.

As mentioned earlier, Company F's products are significantly improved compared to conventional products. Two pieces of core technologies, which are legally bound by patents, and several pieces of tacit knowledge (e.g., system design), which is protected as trade secrets to conceal from the public, to enhance the strength of patent protection. Furthermore, Company $\mathrm{F}$ also separates the duties of employees as a method to protect its IP.

The company has patented the first core technology and filed a patent for the second one (i.e., application in progress). Besides, it is filing the first patent across multiple countries. Company $\mathrm{F}$ decided to apply for patents because the patents enable the company to maintain competitive advantages, such as preventing potential competitors from entry, preventing lawsuits against Company $\mathrm{F}$, and attracting potential investors and buyers of the company. Besides, it turns out that patents play significant roles in Company F's internationalization when expanding into developing countries as they are signal for the quality of the Company's products and technologies.

In short, Company $\mathrm{F}$ is a young, international, and fast-growing company that carries imperative IP, which is key to their business. Patents complementing with several informal protection mechanisms are essential to Company $\mathrm{F}$ in many aspects when it is capturing value from its technologies. 


\subsubsection{Company G}

Company $\mathrm{G}$ is another medical device company in the case selection. Therefore similarly, Company $\mathrm{G}$ is well-funded by the angel investors, key employees, venture capitalists, and government grants. Another similarity is that there are more than half of the employees (i.e., more than seventy people) working on $\mathrm{R} \& \mathrm{D}$ and other technical aspects of the company.

In brief, Company $\mathrm{G}$ owns cutting-edge technologies which are its IPs in its niche field. It was incorporated in 2007 while its formal operation started in 2010, which will be explained later. Today the case company has more than ninety employees, and its global markets include North America and East Asia.

Company G's team is strong in terms of competencies and experience. They are highly educated in the related STEM filed. In addition, the board members and executives have successfully commercialized several medical devices in their prior experience of starting up companies.

When it comes to the IP value capture, the case company deploys patent-dominant strategies. As mentioned earlier, there is a three-year gap between Company G's incorporation and formal operation. The reason is that Company $\mathrm{G}$ was working on not only $\mathrm{R} \& \mathrm{D}$ but also patenting work to lay the groundwork. Back then, a large company was also working on a similar IP, which triggered Company G's patent applications.

The patenting is dominant in Company G's IP value capture not only because the patents establish barriers to entry, but also because of the nature of the medical device industry. Even though the patenting plays a primary role in the value capture, Company $\mathrm{G}$ deploys other 
informal protection mechanisms. For example, there are substantial know-hows on patented technologies which are treated as trade secrets.

In conclusion, similar to the other medical device company in the case selection, Company $G$ deployed patenting as the central mechanism to capture value from its IPs. Furthermore, trade secrets complementing with patent enhanced the value capture mechanism through improved protections.

\subsubsection{Company $\mathrm{H}$}

Company $\mathrm{H}$ is a small company as an online marketplace for the provision of private lessons, which improves and partially substitutes the existing service delivery processes. The Founder bootstrapped and started up the company in 2011. As the company grew, it also won prizes from business contests and received grants from government programs. As of the interview date, the company has six to ten full-time employees and two thousand contract instructors. The company's revenue is in low seven figures, and it operates across Canada, the U.S., and Australia.

Three young professionals formulate Company H's strategies. They come from a commerce background in their respective undergraduate studies. They have combined prior work experience in start-up and corporate context. In terms of the age group, all of them are identified as millennials.

Initially, the company did not have IP strategies as it is not central to their businesses. As mentioned earlier, they provide an online marketplace to bridge the instructors, as service 
providers, and individual customers, which is a B-2-C model. They develop and maintain the marketplace in-house, which is their primary IP, and they make a profit from the technology.

Due to the financial viability and success of this model, Company H's IP is increasingly desirable to other companies, which seek to license in the marketplace technology. Therefore, Company $\mathrm{H}$ improves its model to generate revenues by taking B-2-B into account. In order to facilitate the improvement on the model to generate revenue, Company $\mathrm{H}$ needs formal protection (i.e., patent) of its IP, which has been protected informally (e.g., trade secrets, nondisclosure agreements, and separation of duties). As of the interview date, the company just initiated the patenting process.

In essence, Company $\mathrm{H}$ has not deployed formal IP protection (i.e., patent) yet but it has been protecting its IP informally. The IP has demonstrated its commercial value, so companies in other business sectors want to in-license Company H's technology. Therefore, Company H requires a patent to facilitate business collaboration and starts the application until recently.

\subsection{Cross-Case Analysis}

Based on the interview data collected, the cross-case analysis is presented by describing three strategies of respective case companies: IP creation strategy, value capture strategy, and internationalization strategy. In addition, analysis of different resources (i.e., physical capital, organizational capital, and human capital) will also be conducted.

In general, implementing IP creation strategy creates a foundation for the later value capture for the case companies. The company has not reached a stage to use IPRs to protect its IPs. Usually, the case companies are conducting research and development, design prototype, 
and so forth for IP creation; therefore, companies seldom captured value from their IPs yet when implementing IP creation strategies. Next, when the case companies formulate and implement the value capture strategies, companies plan and undertake activities to generate streams of revenues from their IPs. To implement value capture strategies, companies have a relatively mature model for value capture while they are exploring other avenues in the meantime. The first two strategies are likely progressive while the internationalization strategy is not necessarily. Some companies choose not to internationalize at all, whereas some other companies attempt to internationalize either concurrently with or progressively after the first or second strategies. As for the internationalization, the case company investigate the foreign markets, export its products and services, and engage in other international business activities.

\subsubsection{IP Creation Strategy}

As for this strategy, the primary goal of all case companies was research and development, refining the concepts, and occasionally deigning the prototypes. All case companies created radical-to-the-market IPs and the potential value, especially the commercial value, of their IPs was externally validated by, for example, various business contests and investors (A, B, C, D, F, and H) and the government (to receive grants) (G and H). For example:

"We are functioning on our grants (and) awards (from) competitions right now." (Company B)

"Basically, I got money from the contests and government grants." (Company H)

Therefore, all case companies could be sufficiently but sometimes merely marginally funded by these external organizations to facilitate the preparation. As suggested by the name, 
companies at this stage had not captured value from their IPs yet. Their primary activities were the preparation as mentioned earlier and mainly maintaining the preparation work as several trade secrets. For example, as noted by Company B and Company C:

"That [the preparation so far] would be probably like a trade secret for us now." (Company B)

“(I) really had a lot of trade secrets lined up that I can patent when I add it all at once." (Company C)

As far as the concerns of resources, all case companies did not require too many resources. The case companies required physical capital and human capital resources to an extent that the resources were owned or easily accessible. Particularly for Company H, it entirely utilized internal resources (i.e., bootstrapped) to prepare for value capture. In terms of the human capital resources, the Co-Founders were Co-Inventors, and their knowledge was the main drivers of this stage. If the companies did not have enough internal resources, companies with established Co-Founders would leverage their networks to access such resources without too many challenges. Their radical-to-the-market IPs enabled case companies to mobilize supports from external experts and organizations, which consequently contribute to the human capital resources of case companies primarily in the form of knowledge, competencies, network, and even physical capital resources. For example, the case companies could access to a partner's lab to conduct research and development; in other cases, companies could collaborate with external experts to further leverage their human capital (e.g., knowledge).

“We've basically utilized the university's faculties." (Company B) 
"(An expert) was our mentor while we were at the accelerator." (Company C)

"Some of them are helpful in terms of helping us set up, giving expertise and advisory services and setting (a strategy)." (Company F)

For all the companies, they had a fairly lean organization structure, which enabled them to quickly learn, respond to the market, conduct research and develop IPs. For instance, Company A commented as:

"We have periods throughout which we were moving fairly quickly, so knowledge was changing all the time." (Company A)

In short, all the case companies created radical IPs. The case companies were able to implement their IP creation strategy by leveraging internal and external resources because of the less resource-intensive nature of IP creation. Besides, their radical-to-the-market IPs enabled them to mobilize supports from external experts and organizations and transformed into readily accessible human capital resources. Nonetheless, the case companies required a substantial amount of resources to implement the value capture strategy.

\subsubsection{Value Capture Strategy}

When the companies capture value from their radical-to-the-market IPs, all the case companies chose the product market as their main arenas. Therefore, they sold products (A, B, F, and $\mathrm{G})$ or provided services $(\mathrm{C}, \mathrm{D}$, and $\mathrm{H})$ to generate revenue. In addition, their IPs attracted potential investors $(\mathrm{C}, \mathrm{D}, \mathrm{F}$, and $\mathrm{G})$ and partners (B: distribution and licensing, F: distribution and $\mathrm{H}$ : licensing) for the companies, which are the non-commercial value as defined earlier. For example, in the word of Company $\mathrm{F}$ and $\mathrm{H}$ : 
"The third one (benefit) is the value that it carries for potential investors."

"We have had partners inquired us about it, and maybe it played a role." (Company F)

"As we started to use (our technology) as business-to-business sales, licensing our software." (Company H)

In order to secure the non-commercial value, proper patents on the radical IPs was crucial for the case companies. For example, Company B and Company D stated:

"Using this IPR (patent) we can form partnerships with larger organizations with larger channels and resources for manufacturing and sales." (Company B)

"It is important from the perspective of investors (and) from the perspective of the company." (Company D)

As mentioned earlier, value capture is resource-intensive and required all three types of resources. The companies should access to complementary assets such as research and development equipment, manufacturing facilities and distribution channels (i.e., physical capital assets) regardless of whether they are product-oriented or service-based companies. If there was a resource gap, case companies could address the gap by mobilizing supports from the network. Company B said:

"When it comes to manufacturing, we have a manufacturing lab at the university, and we've been able to speak to the head of the manufacturing lab, and they've agreed for us to use their facilities if we need to." (Company B) 
In addition, the case companies required not only technical competencies but also other multidisciplinary capabilities (e.g., commerce and law) to formulate and execute business strategies to ensure the successful value capture. For instance, in the word of Company F:

"We have strong middle management who are managing operations, project management, manufacturing, supply chain."

"It (the strategy) is mostly on the execution." (Company F)

For companies which are patenting on their radical IPs in progress, they deployed mostly informal IP protection mechanisms. It is also suggested that they needed strong organizational capital resources. For example, the case companies separated duties, so the employees were not able to leak the entire IPs if compromised. On the other hand, the case companies should also have strong coordinating systems (i.e., organizational capital resources) because they were developing their IPs quickly. Company A said:

"For example, our marketing team would never really know how it was built in specifics, they would know the high-level... We were moving really quickly towards the end..." (Company A)

The results again demonstrate the importance of owning and mobilizing human capital resources. For instance, the Founders (or other key individuals) of some companies are seasoned in their respective fields in terms of work and entrepreneur experience ( $\mathrm{C}$ and $\mathrm{G})$. For companies with strong human capital resources as mentioned above, they were well-funded, and formed a multidisciplinary team. Therefore, the employees could devote time to R\&D and business-related tasks (e.g., strategic planning, production, and distribution) instead of resource-seeking tasks 
(e.g., attracting potential investors and finding talents) (e.g., A and B). For example, Company C and $\mathrm{G}$ in contrast to Company $\mathrm{A}$ :

“(A partner) worked at (two large corporations). All those (experience) connect into the existing industry." (Company C)

"At least half or more member are successful serial entrepreneurs in medical devices, and some may even be the former CEOs of listed companies." (Company $G$ )

“(We) decide to stop because we didn't have enough money to last much longer." (Company A)

Lastly as mentioned earlier, all case companies had the patent(s) or were planning to patent even though patenting is costly; accordingly, companies required thorough benefit-cost analysis before patenting. Company $\mathrm{C}$ noted:

"We've secured patents in the past; (however,) the benefit to the cost ratio is kind of questionable." (Company C)

Patenting required not only much money but also a large amount of internal (e.g., related application and management) and external (e.g., lawyer) human capital resources. For example:

"As much as we can spend time and learn about this, we find the best go-to person is just lawyers because they know all the nitty-gritty, they know the loopholes and anything like that." (Company B) 
Not surprisingly, it can be assumed that companies applied patent(s) on their IPs because patenting's perceived benefits outweighing the costs. Nonetheless, the benefits and costs were hard to quantify (even for potential investments), so most companies focused on the noncommercial value, such as the necessity to prevent competition and knowledge leakage in partnership. For instance, as D, F, and $\mathrm{H}$ suggest:

"With the IP (i.e., patents) we kind of have the barrier there so that future competitors or products in the pipeline wouldn't be similar to our product." (Company D)

"There are three (types of) value that bring to the table... One is the deterrence of potential competitors... The second one is obviously to actually enforce and protect our interests, to actually use the patent in a financially viable way... The third one is the value that it carries for potential investors or potential exits down the road" (Company F)

"(Having patent is to protect) from other people (partner) stealing it (the technology)." (Company H)

In sum, the demonstrated non-commercial value of patents which could be captured includes, establishing barriers to entry (all case companies), opening new avenues for revenue generation $(\mathrm{H})$, creating favorable terms in the case of the company's mergers and acquisition or initial public offerings (D and F), quality signal for the IPs and companies (D and F), supporting non-R\&D employees to finish their tasks (D), and attracting potential partners (B: distribution and licensing; F: distribution, and H: licensing; C, D, F, and G: investors). For companies in the 
medical device sector, patenting was more like a common rule in the sector rather than a strategic choice (D and G). For example:

"It might be due to the nature of our industry. In our industry, patents are just very important." (Company G)

For all companies which already had the patent(s), they still used multiple informal protection mechanisms, mostly trade secrets, to complement with patenting to enhance the value capture. For instance:

"I believe the exact programming code for the diagnosis technology (as a trade secret) was not released/disclosed in the patents." (Company D)

\subsubsection{Internationalization Strategy}

Internationalizing case companies capture value from their radical IPs through the product market (i.e., commercial value) as well as forms of non-commercial value. Some companies chose not to internationalize yet because they were focusing on the local market (A and B). For other companies with international scope, internationalization was part of the strategies when case companies were founded. These companies in question became international because of limited local market demand $(\mathrm{G}$ and $\mathrm{H})$, foreign market demand potential $(\mathrm{C}, \mathrm{D}$, and $\mathrm{F})$, or access to complementary assets, such as production facilities (Company F). Internationalization was not challenging for some companies because many companies and their IPs did not require much if any, physical components (e.g., service-based and e-Commerce companies); thus, virtual transactions naturally eliminated the limitation of national borders $(\mathrm{C}, \mathrm{F}$, and $\mathrm{H})$. 
Another similarity to the domestic value capture is that capturing value internationally was resource-intensive. Physical capital (e.g., distribution channels as complementary assets) and human capital resources (e.g., network in foreign countries) were desirable. Patents were an important enabler to overcome the asymmetry of information as potential clients, partners and investors inquired about patenting, which acted as the quality signal for the radical IPs and most importantly, the companies. For example, in the case of Company D and F:

"I would say it (patent) is like (a signal for) legitimized products a little bit more." (Company D)

"In some of the developing countries, this is especially more important, especially with clients." (Company F)

The international value capture mechanisms and resource analysis are comparable to the domestic value capture. It might stem from the lean organization structure, so the companies were able to respond to both the local and foreign situations quickly. Another explanation might be due to the nature of products and services which 1) are IP embedded, so there is no intense competition in foreign countries and 2) easily and universally accepted technologies across different nations.

\subsubsection{Summarizing the Patterns and Differences}

Chapter 4.2 compares and contrasts seven case companies to investigate their strategic patterns and differences through cross-case analysis. In order to mitigate the informationprocessing bias and enhanced the probability to capture novel findings, the cross-case analysis 
was conducted based on three distinct strategies implemented and three types of resources owned and / or mobilized by the case companies.

Table 6 summarizes the key patterns and different among the case companies with a focus on how small companies commercialize their IPs and the important roles of network and radical patents for small companies. The summary conveniently leads to the discussion in Chapter 5 and answers the research questions of this study.

(Intentionally Left Blank) 
Table 6 - Patterns and Differences Among Seven Case Companies

\begin{tabular}{|c|c|}
\hline Patterns & Differences \\
\hline $\begin{array}{l}\text { - IP Creation Strategy } \\
\text { Case companies create radical-to-the-market } \\
\text { intellectual properties, and the value is validated by } \\
\text { external parties } \\
\text { The radical-to-the-market intellectual properties } \\
\text { enable case companies to mobilize supports from } \\
\text { experts and organizations, which consequently } \\
\text { contribute to the human capital resources of case } \\
\text { companies primarily in the form of knowledge, } \\
\text { competencies and network } \\
\text { In general, it is less resource-intensive to } \\
\text { implement and execute the IP creation strategies } \\
\text { Value Capture Strategy } \\
\text { Case companies mainly capture commercial value } \\
\text { through the product market } \\
\text { Case companies recognize the importance of } \\
\text { patents for them to capture non-commercial value } \\
\text { comparable strategies (as mentioned earlier) in the } \\
\text { domestic and international market } \\
\text { Case companies recognize the importance of } \\
\text { human capital resources, in the form of } \\
\text { multidisciplinary competencies and network } \\
\text { Trade secrets, along with other informal protection } \\
\text { mechanisms, complement the use of patents in the } \\
\text { value capture strategy general, case companies have superior } \\
\text { organizational capital resources for the value } \\
\text { capture, whereas they mobilize physical and } \\
\text { human capital resources strategically } \\
\text { In internationalizing case companies deploy } \\
\text { - }\end{array}$ & $\begin{array}{l}\text { - IP Creation Strategy } \\
\text { Case companies have different } \\
\text { initial resources owned and } \\
\text { key individuals with different } \\
\text { characteristics on the team } \\
\text { - Value Capture Strategy } \\
\text { Not all case companies have } \\
\text { had patents on their } \\
\text { intellectual properties; } \\
\text { nonetheless, they aspire to } \\
\text { patent case companies } \\
\text { Not all case or } \\
\text { successfully have owned or } \\
\text { mobilized the desired } \\
\text { resources given their efforts } \\
\text { Some case companies are } \\
\text { open to other commercial } \\
\text { value capture mechanisms } \\
\text { Internationalization Strategy } \\
\text { Not all case companies are } \\
\text { aspired to internationalize }\end{array}$ \\
\hline
\end{tabular}




\section{Chapter 5.0 Discussion}

The overall thesis was designed to investigate two central research questions, namely 1) how small companies capture value from their IPs, and 2) in their value capture, how small companies utilize their physical, organizational, and human capital resources and overcome resource constraints if any. Following Chapter 4, this Chapter continues the discussion of patterns and differences captured from the cases, which leads to three propositions. Even though the thesis is explorative in nature, this chapter relates key results to existing theories to increase the qualitative rigor (Gioia et al., 2013).

\subsection{The Importance of Different Forms of Resources}

Following the line of Barney's (1991) seminal study, which conveniently classified resources into three categories: physical capital, human capital, and organization capital resources, this thesis analyzes the importance of resources to small companies with valuable and radical IPs. It can be argued that small companies own superior organizational capital resources, while there is a shortfall in their physical and human capital resource ownership and accessibility. As most studies on small businesses indicate, small companies in question mobilize resources through the network.

\subsubsection{Organizational Capital Resources: Being Creative and Quick}

In line with studies of Revilla \& Fernández (2012), small companies have superior organizational capital resources to facilitate their value capture; specifically, the flat and lean organizational structure allow their internal informational flow to be smooth, so they are able to 
develop IPs and interact with market swiftly. Besides, as small companies are more creative and less subject to inertias than large companies (Revilla \& Fernández, 2012), which might result in their higher likelihood and abilities to create radical-to-the-market IPs. Accordingly, the role of organizational capital resources in value capture is characterized as making small companies creative and quick.

\subsubsection{Physical Capital Resources: Complementary Assets}

Pertaining to physical capital resources, particularly the complementary assets are of great importance to small companies in question when they capture value in the product market (Gans \& Stern, 2003; Marx \& Hsu, 2015; Teece, 1986), as complementary assets are able to transform IPs into products or services and build company reputation (Agarwal \& Helfat, 2009). Complementary assets include supplement manufacturing facilities, distribution channels, or other assets that deliver complement marketing campaigns or services are conjunct with the IPs of small companies in question to deliver and capture value (James et al., 2013). Most of these case companies choose offices adjacent to the complementary assets. Only one case company was able to own manufacturing assets while others (are making efforts to) mobilize physical capital resources from their network.

\subsubsection{Human Capital Resources: Knowledge, Capabilities, and Network}

Case companies have expressed their crucial needs for human capital resources which are operationalized as multidisciplinary knowledge, capabilities, network, and so forth. Many prior studies have identified the cross-discipline nature of value capture from IPs (Aarikka-Stenroos et al., 2014; Baldwin \& Johnson, 1996; Datta et al., 2015). Companies require not only IP development competencies in the related STEM fields but also other capabilities, notably, 
business management, law, a functioning network, and along with other related human capital resources as well.

With these human capital resources, small companies in question are able to transform their IPs into marketable commodities, and then further, successfully undertake value capture activities. The abovementioned multidisciplinary knowledge, capabilities, and network are particularly imperative to be owned or easily mobilized by the small companies because the current ecosystem for small companies with IPs in Canada has not been well established (Tawfik, 2016). Some case companies also require human capital resources in international business (e.g., network in foreign countries and international business knowledge). To address the human capital needs, few case companies acquire talents to form a multidisciplinary team if well-funded. In most cases, they fill the human capital gap through external channels, such as seeking mentorship, forming an advisory board and collaborating with other organizations.

A stand-alone company is not likely to possess all the resources required to capture value from their IPs (Datta et al., 2015); therefore as suggested by Hagedoorn (1993), small companies network primarily for IP development and value capture motives. In accordance with many studies on small companies, network contributes not only knowledge but also value capture supports to small companies (Aarikka-Stenroos et al., 2014; Gredel et al., 2012; Rogers, 2004). Their network grows like a rolling snowball. For starters, small companies in question establish the network in their respective field to mobilize resources from experts and organizations in the network. At this stage, because their IPs are radical to the market, established external parties are interested in supporting them in exchange for strategic controls, such as being a partner or on the board, as pointed out by the case companies. The case companies can acquire IP development knowledge and sometimes, they can leverage the network of external experts and organizations 
to further grow their own network. In the findings of this thesis, case companies follow this process in an iterative manner to address their gaps in physical capital and other human capital resources when developing and capturing value from their IPs. The discussion leads to the following proposition:

Proposition 1: Small companies with radical intellectual properties actively mobilize supports from more established external parties; when the small companies do so, they grant the external parties strategic controls over their operations.

\subsection{Value Capture Choices of Small Companies}

\subsubsection{Commercial Value Capture: the Product Market}

As introduced in Chapter 4.1, all case companies have created radical-to-the-market IPs (Gans \& Stern, 2003) and their strategy is to capture commercial value through the product market (Gans et al., 2002; Gans \& Stern, 2003) and some of them have implemented the commercial value capture in the international arena (Symeonidou et al., 2017). Even though they are open to other commercial value capture mechanisms, such as the market for "ideas" (Gans \& Stern, 2003), none of them had established such relationships with other companies (e.g., licensing partnership) to enable those transactions.

The underlying reason was complicated. Firstly, the radical-to-the-market IPs of case companies are disruptive in nature; therefore, the rivalry is not intense, and there are no substitutes for the products or services of case companies. Accordingly, case companies are able to access to competitive advantages in the product market (Barney, 1991; Porter, 1979). In 
addition, the radical-to-the-market nature of IPs allows the case companies to further enhance their competitive advantages by mobilizing supports from external parties as discussed earlier.

Furthermore, the sole initial intention of case companies was to develop IP-embedded products, services, or both because it can be argued that the companies did not realize that the value carried in the market for "ideas" ex-ante. Most case companies reported that they formulated and implemented their strategies on a learning-by-doing basis. Even though the case companies are aspired to capture value through the market for "ideas" later, in accordance with Gans \& Stern (2003), the companies in question might need to foreclose the existing, sometimes, profitable value capture avenues to seize the emerging opportunities in the market for "ideas".

From the perspective of resources, it is inflexible for them to switch value capture mechanisms due to their resource limitations and conflict nature between the product market and the market for "ideas" (Gans \& Stern, 2003; Veugelers \& Cassiman, 1999). Small companies in question not only have devoted their resources to IP-related tasks (Rogers, 2004), but they also undertook investments in complementary assets, mitigated risks, and uncertainties, and established market presence while avoiding detection and consequent competitive actions by other companies (Gans \& Stern, 2003). Therefore, it is excessively sophisticated for small companies to undertake multiple value capture avenues, especially managing the nitty-gritty in the collaboration relationships (Rassenfosse, 2012). Besides, radical-to-the-market IPs might underperform when initially being introduced to the market. Therefore, the case companies might be reluctant to capture value through collaboration with other companies because the case companies will be in unfavorable positions (Marx \& Hsu, 2015). 
Unlike the conventional wisdom, it can be argued that small companies are less likely to sell (or license out) their radical IPs to make quick money; instead, they prioritize the value capture through the product market over other commercial value capture mechanisms. Usually, they pursue value capture in the product market due to various reasons as discussed above. The discussion leads to the following proposition:

Proposition 2: Small companies with radical intellectual properties are likely to prioritize the product market value capture mechanism over other value capture mechanisms for the commercial value capture.

\subsubsection{Non-commercial Value Capture: Role of Patenting}

All case companies have developed and protected their IPs by informal protection mechanisms, specifically by trade secrets, before they are or will be granted by patents. The finding is consistent with previous research (Thomä \& Bizer, 2013). When it comes to the purpose of patenting, most companies decide to patent on their radical IPs with an initial intention to establish a barrier to entry and freedom to operate. In other words, case companies applied for patents on their IPs initially for purposes to enhance the commercial value capture. As mentioned earlier, the case companies create radical-to-the-market IPs and are R\&D intensive; according to prior empirical studies, they are likely to patent (Leiponen \& Byma, 2009; Thomä \& Bizer, 2013).

After the case companies patent on their IPs, they still use informal protection mechanisms to enhance the value capture. In most cases, companies use trade secrets to protect know-how (i.e., tacit knowledge) on how to assemble patented pieces into products or services. The findings support the view on the joint use of IP protection mechanisms to enable value 
capture (Gallié \& Legros, 2012; Thomä \& Bizer, 2013). Other forms of informal protection mechanisms including separation of duties, lead time advantages, and trusted relationship with partners also enhanced the commercial value capture.

On the other hand, case companies fail to recognize the importance of other protection mechanisms, especially the importance of other IPRs, such as trademarks and design registration; not to mention the strategic and joint use of them. It might be due to their limited human capital resources so small companies cannot deploy or even understand the importance and use of other IPRs. Besides, it might also due to the limited size of case selection. Accordingly, small companies in question tend to overlook the importance of other IPRs. Besides, trade secrets along with other informal protection mechanisms play a complementary role in the patentdominant strategies of small companies in question.

Furthermore, case companies realized other multifaceted non-commercial value associated with patenting including, opening new avenues for making money, creating favorable terms in the case of the company's mergers and acquisition or initial public offerings, quality signal for the IPs and companies, supporting non-R\&D employees to finish their tasks, and attracting potential partners (including investors).

The findings confirm the signaling function and the non-commercial value of patents (Bessen, 2008; Hsu \& Ziedonis, 2013; Veer \& Jell, 2012). The mechanisms behind the signaling function of patents might be the result of reduced asymmetric information by patenting according to Rassenfosse (2012). Different stakeholders, especially who are less knowledgeable about the likelihood of success and the market potential of the radical IPs, can establish an equal understanding based on the patents through such as the information disclosed. Furthermore, the 
legitimizing process of patenting might be another signal for high-quality IPs and companies. In addition to the value capture in the domestic market, it also can be argued that patents and the reduced asymmetric information are playing a similar role for small companies in question in the international arena based on the findings.

In sum, even though small companies have limited resources to undertake patenting activities, it is argued that they have an emphasis on the importance of patenting, with which they can enhance the commercial value capture and capture multifaceted non-commercial value from their radical-to-the-market IPs. Even though many studies have confirmed the benefits of patents, these studies might have overlooked the importance of being radical.

Generally, an IP is patentable when it is novel, useful, and non-obvious; therefore, at least some aspects of the patents must be new. However, as reported by Belenzon \& Patacconi (2013) the standard of getting patented is diminishing in the North America, so patents assume declining signal for quality along with other non-commercial value. Instead, the underlying IPs' extent of radicalness of should be the focal point. "Radical" is a relative term to "incremental". Radical IPs have a greater novelty than the incremental IPs, where increment IPs are usually the adaptation, refinement, and enhancement of radical IPs (Zobel et al., 2017).

The discussion leads to the following proposition:

Proposition 3: Small companies with patents capture substantial non-commercial value when the patents are radical in the market.

\section{(Intentionally Left Blank)}




\section{Chapter 6.0 Implications and Limitations}

The findings of this thesis suggest patterns or differences in how small companies capture value from their IPs. Specifically, Chapter 5 discusses how small companies commercialize their IPs and the important roles of network and radical patents for small companies. These observations not only are relevant to the theoretical understandings of small companies and their value capture strategies from IPs, but also have implications for business practitioners in this arena and for policymakers who are interested in encouraging small companies to succeed in creating and benefiting from radical IPs.

\subsection{Theoretical Implications}

In addressing the research gap and answering the research questions mentioned at the beginning, this study has contributed in the field of small business by adding the comprehension and empirical validations of how small companies capture value from their radical IPs on the ground of RBV. In summary, the theoretical implications include (1) in what way small companies capture commercial value from their radical IPs, (2) the resource-based advantages and disadvantages of small companies with radical IPs, (3) the importance of network for small companies in question to overcome resource constraints, particularly, the constrains of physical capital and human capital resources, and (4) the multifaceted non-commercial value of patents in both domestic and international value capture processes for small companies with radical IPs.

This study adds nuances to the processes of small companies with radical IPs mobilizing supports from established external parties. As discussed earlier, small companies in question grant the external parties with strategic controls over the companies given external parties 
interested in the radical IPs. In addition, this study provides evidence that for small companies, they are likely to prioritize the product market over other arenas to capture the commercial value due to various reasons when their IPs are radical. Importantly, this study further suggests that the importance of the patents' radicalness - a point that is underemphasized in the IP management literature. The findings of this thesis confirm the non-commercial value carried by the patents. To further illustrate this point, the analysis is concentrated on the radicalness of patents' underlying IPs. Patents are valuable and carry substantial non-commercial value when they are radical in the market.

\subsection{Practical Implications}

For business practitioners, the findings suggest that patents serve multifaceted roles in both domestic value capture processes and internationalization processes; which is in line with multiple prior studies (e.g., Hsu \& Ziedonis, 2013; Rassenfosse, 2012). On the other hand, network, as a form of human capital resources, is particularly important for small companies with IPs as the companies in question require not only access to physical capital resources but also expand their human capital (e.g., multidisciplinary capabilities) further to facilitate the value capture.

Most importantly, the radicalness of IPs is confirmed important as small companies could mobilize supports from established external parties due to radical IPs and capture substantial non-commercial value from radical patents. Furthermore, business practitioners in question should build their IP literacy so they can equip themselves with the knowledge of diverse value capture options. Overall, this thesis depicts several possible trajectories for small companies to capture value from their IPs as a reference. 


\subsection{Policy Implications}

Policymakers in Canada have a demonstrable interest in encouraging companies, especially small companies, to create radical IPs and to capture value from their IPs. Although not much research has been done on this topic, prior studies have come up with conceptual frameworks on various value capture mechanisms (Gans \& Stern, 2003; Marx \& Hsu, 2015; Teece, 1986).

This thesis fills the knowledge gap to understand how Canada's small companies capture value from their radical IPs and the true needs of them. The findings suggest that given their limited resources, Canada's small companies sell products and provide services based on their radical IPs. In addition, this study confirms that small companies in Canada emphasize the importance of patents. Because of the radicalness of their IPs, Canada's small companies are able to mobilize supports from established external parties by granting the parties strategic control.

In order to further encourage value capture of small companies, policymakers need to further enhance the ecosystem for IP-intensive small companies, through the provision of assistance. This means that policymakers will need to establish methods of building small companies' IP literacy and facilitating their access to critical resources. It is therefore imperative that efforts to introduce programs that connect small companies with desired resources, especially human capital resources. Actionable suggestions include events that help small companies build up the network, educational and informative seminars, encouraging innovation intermediaries, and so forth. 


\subsection{Limitations and Directions for Future Research}

Even though this thesis covers small companies across business sectors, it only covers Canada's small companies with radical IPs. Therefore, the discussions are not valid to be generalized to include foreign companies and small companies with not radical IPs. Suggestions for possible topics include exploring the patterns and differences among value capture strategies of small companies outside of Canada, among different or in specific business sectors, products / services, and radical / incremental IPs.

Ideally, this thesis could have addressed the research questions in a more intimate fashion. Given the creditworthiness of a master's thesis, many, if not all, companies are reluctant to provide more sensitive information, such as financial investment received, financial performances, and key networks than the already collected data. Future studies can focus on this

limitation, for example, by investigating the influences of investors on value capture strategies and the influences of value capture strategies on financial performances.

Furthermore, since this thesis finds the importance of network and patents to small companies, it would be fruitful if future research would focus on how companies mobilize supports from the key networks and how they maintain and use them in the best possible manner. Likewise, future studies could explore how small companies decide to patent on their IPs, enforce the exclusive rights, and establish collaborative relationships, specifically licensing, with / without patenting.

In addition, due to the scope of this thesis, this study also overlooks two pivotal aspects on small companies: liabilities of newness and smallness. Stinchcombe (1965) first sheds light 
on the liability of newness, which stems from the uncertainty about the viability of new company. The liability of newness brings challenges to new small companies and the challenges will impact strategies of these companies in question (Lu \& Beamish, 2006). Similarly, established small companies are challenged because of their limited resources and capabilities, which is the central idea of the liability of smallness (Aldrich \& Auster, 1986).

Accordingly, small and young companies might suffer from the liabilities of newness while small and established companies might still suffer from the liabilities of smallness. Both liabilities might negatively affect small companies to mobilize the external resources, such as complementary assets, knowledge, capabilities, and so forth (Djupdal \& Westhead, 2015), which could further have impacts on the value capture, for example, the commercial (non-commercial) value capture and patenting activities. Future studies on this topic are recommended to include the effects of dual liabilities.

Future studies may also address the relationship between internationalization of small companies and their value capture from IPs. Through in-depth interviews with business practitioners who currently operate, or have attempted to operate, internationalizing small company which has valuable IPs, these studies could better depict how IPs play a role in these companies' internationalization. This type of studies could provide specific trajectories and strategies that aspired practitioners in this field can adopt.

\section{(Intentionally Left Blank)}




\section{Chapter 7.0 Conclusion}

The overall study aims to answer two research questions, and they are: (1) how small companies capture value from their intellectual properties and (2) in their value capture, how small companies utilize their physical, organizational, and human capital resources and overcome resource constraints if any. To do so, this thesis uses primary interview data to assess the value capture strategies of small companies in Canada. A set of within- and cross-case analysis is conducted to investigate patterns in the case selection and differences among seven cases. By analyzing the empirical case findings in the light of IP management theory and resource-based view (RBV), three propositions about how small companies commercialize their IPs and the important roles of network and radical patents for small companies are discussed. Accordingly, theoretical, practical, and policy implications which are followed by the limitations and directions for future research are explained. The gaps that are left open by this thesis would be best addressed by future research.

(Intentionally Left Blank) 


\section{Appendix}

\section{Appendix 1 - Code Book}

\begin{tabular}{|c|c|}
\hline Name & Description \\
\hline basic info - company & $\begin{array}{l}\text { basic information about the case company, such as age, size, and } \\
\text { so forth }\end{array}$ \\
\hline age - company & age of the case company \\
\hline other info & $\begin{array}{l}\text { notable information other than age, size, and performance of the } \\
\text { case company }\end{array}$ \\
\hline $\begin{array}{l}\text { multidisciplinary } \\
\text { team }\end{array}$ & $\begin{array}{l}\text { coded if the case company owns a multidisciplinary team, which } \\
\text { includes experts from multiple fields, such as business, engineer, } \\
\text { and so forth }\end{array}$ \\
\hline $\begin{array}{l}\text { spin-off of large } \\
\text { company }\end{array}$ & coded if the case company is a spin-off of a large company \\
\hline size - num of emp & $\begin{array}{l}\text { the number of full-time employees measures the size of the case } \\
\text { company }\end{array}$ \\
\hline r\&d intensity & $\begin{array}{l}\text { in this dataset, the number of employees who are responsible for } \\
\text { research and development, which is the proxy to r\&d intensity }\end{array}$ \\
\hline business model & $\begin{array}{l}\text { a business model describes the rationale of how an organization } \\
\text { creates, delivers, and captures value }\end{array}$ \\
\hline $\begin{array}{l}\text { business model } \\
\text { innovation }\end{array}$ & $\begin{array}{l}\text { change of an existing business model or the creation of a new } \\
\text { business model that better satisfies the needs of the customer than } \\
\text { existing business model }\end{array}$ \\
\hline $\begin{array}{l}\text { commercialization } \\
\text { strategy }\end{array}$ & $\begin{array}{l}\text { the process of introducing a new product or production method } \\
\text { into commerce-making it available on the market }\end{array}$ \\
\hline value proposition & $\begin{array}{l}\text { explanations about why a consumer should buy a product or use a } \\
\text { service including value added to and problems solved for } \\
\text { customers }\end{array}$ \\
\hline primary benefits & $\begin{array}{l}\text { value added to the target market and / or how the problems of the } \\
\text { target market are solved }\end{array}$ \\
\hline product & $\begin{array}{l}\text { including products and services which case companies offer to the } \\
\text { market }\end{array}$ \\
\hline target market & $\begin{array}{l}\text { the customers including individuals and institutions which the case } \\
\text { companies serve }\end{array}$ \\
\hline
\end{tabular}




\begin{tabular}{|c|c|}
\hline competition environment & $\begin{array}{l}\text { information that is relevant to competition, such as the competitors, } \\
\text { competitive advantages of case companies and so forth }\end{array}$ \\
\hline $\begin{array}{l}\text { advantages of } \\
\text { competitors }\end{array}$ & the competitive advantages achieved by (in)direct competitors \\
\hline $\begin{array}{l}\text { competitive } \\
\text { advantages }\end{array}$ & $\begin{array}{l}\text { a condition or circumstance that puts the case company in a } \\
\text { favorable or superior business position }\end{array}$ \\
\hline conventional products & $\begin{array}{l}\text { conventional products are usually used, or that has been in use for } \\
\text { a long time }\end{array}$ \\
\hline indirect competition & $\begin{array}{l}\text { competitors that make different products (or offer different } \\
\text { services) but target the same customers and aim to satisfy the same } \\
\text { needs }\end{array}$ \\
\hline demo info - individual & $\begin{array}{l}\text { demographic information (e.g., age, gender, education, and so } \\
\text { forth) of key individuals including founders, senior managers, } \\
\text { investors, and so forth in case companies }\end{array}$ \\
\hline age - individual & $\begin{array}{l}\text { age of the interview participant and other key employees in the } \\
\text { case companies }\end{array}$ \\
\hline edu info & $\begin{array}{l}\text { education and training received by participants or other key } \\
\text { individuals of case companies that support their job responsibilities }\end{array}$ \\
\hline gender & $\begin{array}{l}\text { any explicit or implicit (e.g., the use of he or she) data that } \\
\text { indicates the gender of key individuals in the case company }\end{array}$ \\
\hline key individuals & $\begin{array}{l}\text { overview of key individuals including founders, senior managers, } \\
\text { investors, and so forth in case companies who are responsible for } \\
\text { strategic decision making, especially IP and commercialization } \\
\text { decisions }\end{array}$ \\
\hline responsibilities & $\begin{array}{l}\text { job responsibilities, especially roles in IP and commercialization, } \\
\text { of interview participants or other key individuals of their case } \\
\text { company }\end{array}$ \\
\hline exp and skill set & $\begin{array}{l}\text { professional experience and skill set of the case company's key } \\
\text { individuals including founders, senior managers, investors, and so } \\
\text { forth }\end{array}$ \\
\hline skill set & $\begin{array}{l}\text { the skill set of participants or other key individuals that supports } \\
\text { their job responsibilities in their case company, for example, } \\
\text { programming and coding }\end{array}$ \\
\hline start-up exp & experience of working in or owning start-ups \\
\hline
\end{tabular}




\begin{tabular}{|c|c|}
\hline work exp & $\begin{array}{l}\text { experience of working in mature companies, such as medium-sized } \\
\text { companies or large corporations }\end{array}$ \\
\hline funding & $\begin{array}{l}\text { sources of financing for the case company, such as angel investors, } \\
\text { venture capitals, bootstrapping, and so forth }\end{array}$ \\
\hline angel investor & $\begin{array}{l}\text { high net worth individual who provides capital for a business start- } \\
\text { up, usually in exchange for convertible debt or ownership equity }\end{array}$ \\
\hline bootstrapping & $\begin{array}{l}\text { An individual is said to be bootstrapping when he / she attempts to } \\
\text { found and build a company from personal finances or the operating } \\
\text { revenues of the new company }\end{array}$ \\
\hline crowdfunding & $\begin{array}{l}\text { funding the case company by raising small amounts of money from } \\
\text { a large number of people, typically via the Internet }\end{array}$ \\
\hline funds available & amount of money that has been raised by the case companies \\
\hline government grant & the financial assistance provided by the governments \\
\hline $\begin{array}{l}\text { other sources of } \\
\text { funding }\end{array}$ & $\begin{array}{l}\text { other sources of funding that have not been covered by the } \\
\text { codebook }\end{array}$ \\
\hline pitch contest & $\begin{array}{l}\text { events where the case company won capital, investor (and advisor) } \\
\text { networks, and so forth to develop the company }\end{array}$ \\
\hline venture capital & $\begin{array}{l}\text { a form of financing that is provided by firms or funds to small, } \\
\text { early-stage, emerging firms that are deemed to have high growth } \\
\text { potential, or which have demonstrated high growth }\end{array}$ \\
\hline series a & $\begin{array}{l}\text { the case company's first significant round of venture capital } \\
\text { financing }\end{array}$ \\
\hline informal protection & $\begin{array}{l}\text { informal IP may take various forms; secrecy, confidentiality } \\
\text { agreements, lead time, and complexity (of design) }\end{array}$ \\
\hline contracts & $\begin{array}{l}\text { use of contracts (e.g., non-disclosure agreement) as an informal } \\
\text { method to protect the case company's IP }\end{array}$ \\
\hline lead time & creating or improving IPs quicker than the competitors \\
\hline $\begin{array}{l}\text { reasons for informal } \\
\text { protection }\end{array}$ & reasons for informal protection \\
\hline separation of duties & having more than one person required to complete a task \\
\hline tacit knowledge & $\begin{array}{l}\text { the kind of knowledge that is difficult to transfer to another person } \\
\text { by means of writing it down or verbalizing it }\end{array}$ \\
\hline trade secrets & $\begin{array}{l}\text { a trade secret is any confidential information that confers a } \\
\text { competitive advantage and value to its case company by virtue of } \\
\text { its secrecy }\end{array}$ \\
\hline
\end{tabular}




\begin{tabular}{|c|c|}
\hline $\begin{array}{l}\text { internationalization } \\
\text { strategy }\end{array}$ & $\begin{array}{l}\text { how case companies take steps to increase its footprint or client } \\
\text { base outside of its country of domicile and into international } \\
\text { markets }\end{array}$ \\
\hline foreign markets & any markets outside of the case company's own country \\
\hline foreign operations & $\begin{array}{l}\text { a subsidiary, associate, joint venture, or branch whose activities are } \\
\text { based in a country or currency other than that of the reporting } \\
\text { entity }\end{array}$ \\
\hline $\begin{array}{l}\text { importance of } \\
\text { internationalization }\end{array}$ & the importance of internationalization to the case companies \\
\hline $\begin{array}{l}\text { role of ip in } \\
\text { internationalization }\end{array}$ & $\begin{array}{l}\text { the role IP played in the case company's internationalization } \\
\text { (strategy) }\end{array}$ \\
\hline leveraging network & $\begin{array}{l}\text { the activities are undertaken by case companies to leverage the } \\
\text { network to access essential resources }\end{array}$ \\
\hline patent & $\begin{array}{l}\text { patent-related themes, such as the benefits of patenting, challenges } \\
\text { of patenting, and roles of patents in case company's specific } \\
\text { operations }\end{array}$ \\
\hline $\begin{array}{l}\text { challenges of } \\
\text { patenting }\end{array}$ & $\begin{array}{l}\text { the challenges that the case companies face when patenting their } \\
\text { IPs }\end{array}$ \\
\hline draft patent - external & $\begin{array}{l}\text { the external resources used to get patented, including financial, } \\
\text { human, and other resources }\end{array}$ \\
\hline draft patent - internal & $\begin{array}{l}\text { the internal resources used to get patented, including financial, } \\
\text { human, and other resources }\end{array}$ \\
\hline $\begin{array}{l}\text { internationalization of } \\
\text { patents }\end{array}$ & the regions where patents are effective \\
\hline patent details & $\begin{array}{l}\text { the products and technologies that are patented, number of patents, } \\
\text { and so forth }\end{array}$ \\
\hline patent licensing & licensing of patents, if applicable \\
\hline reasons for patenting & $\begin{array}{l}\text { the reasons why the case companies decide (intend) to apply for } \\
\text { patents }\end{array}$ \\
\hline roles of patents & $\begin{array}{l}\text { what the roles of patents are (will be) playing in the case } \\
\text { companies }\end{array}$ \\
\hline status of patents & $\begin{array}{l}\text { the application status of patents, for example, the patents were } \\
\text { granted when the case company was founded, or the patents are in } \\
\text { the application }\end{array}$ \\
\hline revenue and cash flow & annual revenue and cash flow information \\
\hline
\end{tabular}




\section{Appendix 2 - Interview Guide}

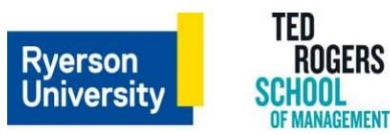

Semi-structured Interview Guide

\begin{tabular}{|c|c|c|}
\hline Activity & Comments & $\begin{array}{c}\text { Approx. } \\
\text { Time }\end{array}$ \\
\hline 1 - Introduction & $\begin{array}{l}\text { Confirmation of consent } \\
\text { Brief the participant } \\
\text { Introduce self } \\
\text { Explain the goals of the interview } \\
\text { Review interview method, use of data, } \\
\text { confidentiality, and so on }\end{array}$ & $5 \mathrm{~min}$ \\
\hline $2-$ Structured Topics & See below & $\begin{array}{c}20-30 \\
\min \end{array}$ \\
\hline $\begin{array}{l}3 \text { - General questions and open } \\
\text { dialogue with participant }\end{array}$ & $\begin{array}{l}\text { Open-ended questions about the IP } \\
\text { (commercialization) strategies used by the } \\
\text { participant's business, for example, the } \\
\text { participant sharing how his/her business } \\
\text { once commercialized one patent }\end{array}$ & $\begin{array}{l}0-20 \\
\min \end{array}$ \\
\hline 4 - Closing comments & Collection of paperwork, and so on & $5 \mathrm{~min}$ \\
\hline
\end{tabular}

\section{Questions}

1) Business information
a) Age of business?
b) Size of business (number of full-time and part-time employees)?
c) (Average) annual revenue?
d) Average annual revenue growth (and expected growth)?
e) Average annual employee growth (and expected growth)?
f) Other indicator/measure in the industry/field?

2) Owner/Founder/Senior Manager information
a) Age?
b) Education (type - business, STEM, or law, and level)? 
c) Prior start-up experience?

d) Prior industry experience?

e) Prior experience of IP strategy?

f) Prior experience of international business (export, IJV, etc.)?

3) Business operation

a) The initial intention with your business? Has it changed?

b) What does your business precisely offer (new or improved products/services/production processes/organizational method/selling method)?

c) Current/expected customers served [domestic/foreign and which market(s)]?

d) What is the value of the product/service to the customers?

e) How is that value delivered to the customers?

f) Critical technologies and competences when delivering values (own/license patent, trademark, etc.)?

4) Intellectual property (IP) strategies

a) Are there similar companies in your industry? What innovations make you outstanding?

b) What critical innovation is required for ongoing success?

i) To what extent is your company engaged in such innovation activities? ${ }^{1}$

c) How are you/is the company protecting your intellectual assets?

d) Have you filed/do you plan on filing patents/trademarks?

i) If yes:

(1) How many?

(2) Did you use any external advice/assistance?

(3) Information about and support provided by government/bank/investors/law firms before/while/after filing you IP?

\footnotetext{
${ }^{1} R \& D$ costs / sales, or $R \& D$ employees, etc.
} 
(4) What are/were the strategic goals of filing them? ${ }^{2}$ Has your company achieved its goals?

(5) How did you use your IP: products/services, license, and / or joint ventures?

ii) If none of the above: why?

e) Open-ended: what are your IP strategies?

f) Open-ended: legal protections of IP are considered formal protections, do your company use any less formal (informal) methods to protects your IP?

i) Which protection (formal/semi-formal/informal) is more favorable to your company? Please provide further details.

5) Performances (benefits) of IP strategies

a) Financial - funding, grants, ROA, ROE, and sales growth?

i) If you prefer not to answer precisely: compare to the peers in the industry: high, low, the same?

b) Non-financial:

i) Except for the performances/benefits mentioned above, are there any other performances/benefits?

c) Internationalization

i) Did Internationalization play any part in your decisions regarding IP? Whether yes or no, please provide further details.

d) Does your company access to competitive advantages through the IP? Please provide further details such as examples.

\footnotetext{
${ }^{2}$ Examples if need prompt: VC (funding), incentive to employees, government grants, recognition by customers and suppliers, getting acquired, avoid infringement, freedom to operate, patentability of ideas assessment, identifying potential partners
} 


\section{References}

Aarikka-Stenroos, L., Sandberg, B., \& Lehtimäki, T. (2014). Networks for the commercialization of innovations: A review of how divergent network actors contribute. Industrial Marketing Management, 43, 365-381.

Agarwal, R., \& Helfat, C. E. (2009). Strategic Renewal of Organizations. Organization Science, 20, 281-293.

Alam, R. M. K., \& Newaz, M. N. (2016). Intellectual property rights commercialization: impact on strategic competition. The Business \& Management Review; London, 8, 21-27. London, United Kingdom, London: The Academy of Business and Retail Management (ABRM).

Aldrich, H., \& Auster, E. R. (1986). Even dwarfs started small: Liabilities of age and size and their strategic implications. Research in Organizational Behavior, 8, 165-198.

Amara, N., Landry, R., \& Traoré, N. (2008). Managing the protection of innovations in knowledge-intensive business services. Research Policy, 37, 1530-1547.

Audretsch, D., \& Vivarelli, M. (1994). Small firms and R\&D spillovers: Evidence from Italy. Revue d'économie Industrielle, 67, 225-237.

Baldwin, J. R., \& Johnson, J. (1996). Business strategies in more- and less-innovative firms in Canada. Research Policy, 25, 785-804.

Barney, J. (1991). Firm Resources and Sustained Competitive Advantage. Journal of Management, 17, 99-120.

Baumol, W. J. (2004). Entrepreneurial Enterprises, Large Established Firms and Other Components of the Free-Market Growth Machine. Small Business Economics, 23, 9-21. 
Belenzon, S., \& Patacconi, A. (2013). Innovation and firm value: An investigation of the changing role of patents, 1985-2007. Research Policy, 42, 1496-1510.

Belgraver, H., \& Verwaal, E. (2018). Organizational capital, production factor resources, and relative firm size in strategic equity alliances. Small Business Economics, 50, 825-849.

Bessen, J. (2008). The value of U.S. patents by owner and patent characteristics. Research Policy, 37, 932-945.

Blind, K., Edler, J., Schmoch, U., Anderson, B., Howells, J., Miles, I., ... Hipp, C. (2003). Patents in the service industries (No. EC Contract No ERBHPV2-CT-1999-06). Fraunhofer Institute Systems and Innovation Research.

Block, J. H., De Vries, G., Schumann, J. H., \& Sandner, P. (2014). Trademarks and venture capital valuation. Journal of Business Venturing, 29, 525-542.

Borys, B., \& Jemison, D. B. (1989). Hybrid Arrangements as Strategic Alliances: Theoretical Issues in Organizational Combinations. The Academy of Management Review, 14, 234249.

Brant, J., \& Lohse, S. (2013). Enhancing Intellectual Property Management and Appropriation by Innovative SMEs (SSRN Scholarly Paper No. ID 2380212). Rochester, NY: Social Science Research Network.

Brusoni, S., Prencipe, A., \& Pavitt, K. (2001). Knowledge Specialization, Organizational Coupling, and the Boundaries of the Firm: Why Do Firms Know More Than They Make? Administrative Science Quarterly, 46, 597-621.

Canadian Intellectual Property Office. (2016, October 17). Understand the basics. Retrieved September 16, 2018, from https://www.ic.gc.ca/eic/site/cipointernetinternetopic.nsf/eng/wr03585.html?Open\&wt_src=cipo-ip-main 
Candelin-Palmqvist, H., Sandberg, B., \& Mylly, U.-M. (2012). Intellectual property rights in innovation management research: A review. Technovation, 32, 502-512.

Castellaneta, F., Conti, R., Veloso, F. M., \& Kemeny, C. A. (2016). The effect of trade secret legal protection on venture capital investments: Evidence from the inevitable disclosure doctrine. Journal of Business Venturing, 31, 524-541.

Datta, A., Mukherjee, D., \& Jessup, L. (2015). Understanding commercialization of technological innovation: taking stock and moving forward. R\&D Management, 45, 215249.

Djupdal, K., \& Westhead, P. (2015). Environmental certification as a buffer against the liabilities of newness and smallness: Firm performance benefits. International Small Business Journal: Researching Entrepreneurship, 33, 148-168.

Eisenhardt, K. M. (1989). Building Theories from Case Study Research. The Academy of Management Review, 14, 532-550.

Eisenhardt, K. M., \& Graebner, M. E. (2007). Theory Building From Cases: Opportunities And Challenges. Academy of Management Journal, 50, 25-32.

Freel, M., \& Robson, P. J. (2017). Appropriation strategies and open innovation in SMEs. International Small Business Journal, 35, 578-596.

Gallié, E.-P., \& Legros, D. (2012). French firms' strategies for protecting their intellectual property. Research Policy, 41, 780-794.

Gans, J. S., Hsu, D. H., \& Stern, S. (2002). When Does Start-Up Innovation Spur the Gale of Creative Destruction? RAND Journal of Economics, 33, 571-586.

Gans, J. S., \& Persson, L. (2013). Entrepreneurial commercialization choices and the interaction between IPR and competition policy. Industrial and Corporate Change, 22, 131-151. 
Gans, J. S., \& Stern, S. (2003). The product market and the market for "ideas":

commercialization strategies for technology entrepreneurs. Research Policy, 32, 333-350.

Gioia, D. A., Corley, K. G., \& Hamilton, A. L. (2013). Seeking Qualitative Rigor in Inductive Research: Notes on the Gioia Methodology. Organizational Research Methods, 16, 1531.

Gredel, D., Kramer, M., \& Bend, B. (2012). Patent-based investment funds as innovation intermediaries for SMEs: In-depth analysis of reciprocal interactions, motives and fallacies. Technovation, 32, 536-549.

Guest, G., Bunce, A., \& Johnson, L. (2006). How Many Interviews Are Enough?: An Experiment with Data Saturation and Variability. Field Methods, 18, 59-82.

Hagedoorn, J. (1993). Understanding the Rationale of Strategic Technology Partnering: Interorganizational Modes of Cooperation and Sectoral Differences. Strategic Management Journal, 14, 371-385.

Hall, B. H., Helmers, C., Rogers, M., \& Sena, V. (2013). The importance (or not) of patents to UK firms. Oxford Economic Papers, 65, 603-629.

Hall, B. H., Helmers, C., Rogers, M., \& Sena, V. (2014). The Choice between Formal and Informal Intellectual Property: A Review. Journal of Economic Literature, 52, 375-423.

Henkel, J., Rønde, T., \& Wagner, M. (2015). And the winner is-Acquired. Entrepreneurship as a contest yielding radical innovations. Research Policy, 44, 295-310.

Holton, J. A. (2007). The Coding Process and Its Challenges. In The SAGE Handbook of Grounded Theory (pp. 265-289). SAGE Publications Ltd.

Hsu, D. H., \& Ziedonis, R. H. (2013). Resources as dual sources of advantage: Implications for valuing entrepreneurial-firm patents. Strategic Management Journal, 34, 761-781. 
Innovation, Science and Economic Development Canada. (2015). Summary of the Survey on Financing and Growth of Small and Medium Enterprises, 2014 [Statistical Reports; Data Sets]. Ottawa: Innovation, Science and Economic Development Canada.

Innovation, Science and Economic Development Canada. (2016). Key Small Business Statistics June 2016. Ottawa: Innovation, Science and Economic Development Canada.

Innovation, Science and Economic Development Canada. (2018, April 26). Intellectual Property Strategy [Home page]. Retrieved January 25, 2019, from https://www.ic.gc.ca/eic/site/108.nsf/eng/home

James, S. D., Leiblein, M. J., \& Lu, S. (2013). How Firms Capture Value From Their Innovations. Journal of Management, 39, 1123-1155.

Katila, R., \& Shane, S. (2005). When Does Lack of Resources Make New Firms Innovative? Academy of Management Journal, 48, 814-829.

Kitching, J., \& Blackburn, R. A. (2003). Innovation, Intellectual Property and Informality: Evidence from a Study of Small Enterprises and Some Implications for Policy. Retrieved from https://papers.ssrn.com/abstract=1510555

Kotala, S., Päällysaho, S., \& Kuusisto, J. (2010). Finland: Intellectual asset management among high-growth SMEs. In OECD, High-Growth Enterprises: What Governments Can Do to Make a Difference (pp. 157-177). Paris: OECD Publishing.

Lawson, B., \& Samson, D. (2001). Developing innovation capability in organisations: a dynamic capabilities approach. International Journal of Innovation Management, 05, 377-400.

Lee, S., Park, G., Yoon, B., \& Park, J. (2010). Open innovation in SMEs-An intermediated network model. Research Policy, 39, 290-300. 
Leiponen, A., \& Byma, J. (2009). If you cannot block, you better run: Small firms, cooperative innovation, and appropriation strategies. Research Policy, 38, 1478-1488.

Llerena, P., \& Millot, V. (2013). Are Trade Marks and Patents Complementary or Substitute Protections for Innovation. Presented at the DRUID conference, Copenhagen, Denmark. Locke, K. (2003). Grounded Theory in Management Research. 6 Bonhill Street, London EC2A 4PU: SAGE Publications, Ltd.

Lu, J. W., \& Beamish, P. W. (2006). Partnering strategies and performance of SMEs' international joint ventures. Journal of Business Venturing, 21, 461-486.

Marx, M., \& Hsu, D. H. (2015). Strategic switchbacks: Dynamic commercialization strategies for technology entrepreneurs. Research Policy, 44, 1815-1826.

Motohashi, K. (2008). Licensing or not licensing? An empirical analysis of the strategic use of patents by Japanese firms. Research Policy, 37, 1548-1555.

Neuhausler, P. (2012). The use of patents and informal appropriation mechanisms_-Differences between sectors and among companies. Technovation, 32, 681-693.

OECD. (2005). Oslo Manual: Guidelines for Collecting and Interpreting Innovation Data. In The Measurement of Scientific and Technological Activities (3rd ed.). Paris: OECD Publishing.

Petrick, I., Rayna, T., \& Striukova, L. (2014). The Challenges of Intellectual Property: Creating and Managing IP for a New Age of Innovation. Research-Technology Management, 57, 9-10.

Pettigrew, A. M., Woodman, R. W., \& Cameron, K. S. (2001). Studying Organizational Change and Development: Challenges for Future Research. The Academy of Management Journal, 44, 697-713. 
Porter, M. E. (1979, March 1). How Competitive Forces Shape Strategy. Harvard Business Review, (March 1979). Retrieved from https://hbr.org/1979/03/how-competitive-forcesshape-strategy

Price, J. M. C. (2010). Coding: Open Coding. In A. Mills, G. Durepos, \& E. Wiebe (Eds.), Encyclopedia of Case Study Research. 2455 Teller Road, Thousand Oaks California 91320 United States: SAGE Publications, Inc.

Rassenfosse, de G. (2012). How SMEs exploit their intellectual property assets: evidence from survey data. Small Business Economics, 39, 437-452.

Revilla, A. J., \& Fernández, Z. (2012). The relation between firm size and R\&D productivity in different technological regimes. Technovation, 32, 609-623.

Rogers, M. (2004). Networks, Firm Size and Innovation. Small Business Economics, 22, 141153.

Romney, A. K., Weller, S. C., \& Batchelder, W. H. (1986). Culture as Consensus: A Theory of Culture and Informant Accuracy. American Anthropologist, 88, 313-338.

Rouse, M. J., \& Daellenbach, U. S. (1999). Rethinking research methods for the resource-based perspective: isolating sources of sustainable competitive advantage. Strategic Management Journal, 20, 487-494.

Saunders, M., Lewis, P., \& Thornhill, A. (2009). Research Methods for Business Students. Prentice Hall.

Stinchcombe, A. L. (1965). Social structure and organizations. Indianapolis, IN: Bobbs-Merrill. /z-wcorg/. 
Symeonidou, N., Bruneel, J., \& Autio, E. (2017). Commercialization strategy and internationalization outcomes in technology-based new ventures. Journal of Business Venturing, 32, 302-317.

Tawfik, M. J. (2016). Addressing a Gap in Canada's Global Innovation Strategy. Retrieved from https://www.cigionline.org/publications/addressing-gap-canadas-global-innovationstrategy

Teece, D. J. (1986). Profiting from technological innovation: Implications for integration, collaboration, licensing and public policy. Research Policy, 15, 285-305.

Thomä, J., \& Bizer, K. (2013). To protect or not to protect? Modes of appropriability in the small enterprise sector. Research Policy, 42, 35-49.

Veer, T., \& Jell, F. (2012). Contributing to markets for technology? A comparison of patent filing motives of individual inventors, small companies and universities. Technovation, $32,513-522$.

Veugelers, R., \& Cassiman, B. (1999). Make and buy in innovation strategies: evidence from Belgian manufacturing firms. Research Policy, 28, 63-80.

Veugelers, R., \& Schneider, C. (2018). Which IP strategies do young highly innovative firms choose? Small Business Economics, 50, 113-129.

Wernerfelt, B. (1984). A Resource-Based View of the Firm. Strategic Management Journal, 5, $171-180$.

WIPO. (2012). What is Intellectual Property? World Intellectual Property Organization.

Zobel, A.-K., Lokshin, B., \& Hagedoorn, J. (2017). Formal and informal appropriation mechanisms: The role of openness and innovativeness. Technovation, 59, 44-54. 